\title{
THE PAST AND FUTURE OF SAME-SEX RELATIONSHIP IN EUROPE (THE ANALYSIS OF EU AND ECTRH LAW STANDARDS IN VIEW OF THEIR INFLUENCE ON NATIONAL CONSTITUTIONAL STANDARDS)
}

\author{
Lana Kovačić Markić, LLM, Constitutional Law Adviser \\ Constitutional Court of the Republic of Croatia \\ Trg Svetog Marka 4, Zagreb \\ lana_kovacic-markic@usud.hr
}

\begin{abstract}
The purpose of this paper is to examine the scope of the CJEU's and ECtRH's standards of protection of same-sex relationships as new modern realities of family life and the same-sex couples' rights, insofar as it concerns human rights - the right to private and family life, dignity, equality and non-discrimination. The legal regulation of same-sex relationships as a family law issue is primarily matter of national law. Consequently, the divergent views on this issue in national jurisdiction raise complex questions requiring adequate answers and clear standards at EU and International (Convention) levels. Therefore, the author (by case study method, normative and comparative analyses) gives an overview of the progress of the protection of same-sex couples' rights on the national level, with particular reference to the Republic of Croatia but also at EU and Convention levels. The paper focuses on the CJEU and ECtRH case law as regards the same-sex relationships and same-sex couples' rights and offers landmark cases with an analysis of the most recent judgments. In connection to the latter, a brief discussion of the nature of EU and Convention legal orders and the role of two European Courts within these legal orders is given as well as their interrelation on this issue. The paper will try to provide an answer to the question how the EU and Conventional law standards that have been established regarding the legal recognition of same-sex relationships and protection of same-sex couples rights influenced a national constitutional standard, with an analysis of two most important decisions of the Constitutional Court of the Republic of Croatia directly concerning the same-sex couples rights.
\end{abstract}

Keywords: Same-sex couple, Same-sex marriage, Same-sex partnership, Non-discrimination, CJEU, ECtRH, Constitutional Court of the Republic of Croatia 


\section{INTRODUCTION}

The legal recognition of same-sex relationships is one of the most controversial topics in modern society that leads to complex legal issues to which different states provide different solutions. These issues include the difference between same-sex marriages and registered partnerships but also unregistered partnerships, as well as the access of same-sex couples to adoption or employment benefits or non-recognition of same-sex relationships in cross-border situations. The legal regulation of same-sex relationships as a family law issue belongs to full competence of each Member State. ${ }^{1}$ Consequently there are divergent views in each Member State, and wider on the Convention/Council of Europe level (hereinafter: CoE), starting from a very liberal approach as opening up marriage to same-sex couples to no legal recognition of same-sex relationships, where some Member States defined marriage in their Constitutions as a union of a man and a woman and have thus imposed explicit constitutional ban for same-sex marriages. Therefore, the European Union (hereinafter: EU or Union) and International (Convention) law must find adequate answers and provide a clear legal standard for the protection of same-sex couples.

The aim of this paper is to examine the scope of the two European Courts - the European Court of Human Rights (hereinafter: ECtHR) and the Court of Justice of the European Union (hereinafter: CJEU) standards of protection of same-sex couples as regards human rights - the right to private and family life, dignity, equality, non-discrimination and especially in EU scope, when it has an implication for the internal market, in the sense of family reunification. Firstly, the author, by using a case study method, normative and comparative analyses, gives an overview of legal recognition and the progress of same-sex relationships in Europe. The paper focuses on the regulation of same-sex relationships and protection under national law of the Member States by analysing different models of legal protection in selected national legislations of the EU, and with a particular emphasis on the Republic of Croatia. The paper offers useful insights into the matter of EU regulation and Convention regulation of this issue and provides an overview on the case law of the CJEU and ECtRH, especially landmark cases and analysis of the most recent judgments in this regard. Furthermore, the paper briefly discusses the CJEU's and ECtRH's roles and their interrelation on this issue. A relevant case law of the Constitutional Court of the Republic of Croatia (hereinafter: Constitutional Court) is given as well and the meaning, content and legal effect of the two most important decisions of the Constitutional Court directly concerning same-

About competence of the EU in a cross-border family law, see: Bačić Selanec, N.; Bell C., Who is a "Spouse" Under the Citizens' Rights Directive? The Prospect of Mutual Recognition of Same-Sex Marriages in the EU, European Law Review, vol. 41, no. 5, 2016, pp. 658-660 
sex couples are examined. Finally, the paper will try to provide an answer to the question how the EU and Conventional law standards that have been established regarding the legal recognition of same-sex relationships and protection of samesex couples influenced a national constitutional standard.

\section{LEGAL RECOGNITION OF SAME-SEX RELATIONSHIPS IN EUROPE}

The same-sex relationship in the meaning of law is a relationship between two persons of same sex and it could be formalized in the form of same-sex marriage, registered same-sex partnership - registered before a competent authority or de facto same-sex partnership (non-registered union). Discussion about whether to permit same-sex couples to formalize their relationship is one of the most contested issues in Europe and wider, e.g. in the United States (hereinafter: US). ${ }^{2}$

The level of legal recognition and protection of same-sex couples' rights in particular, vary greatly across the Europe, because the regulation of civil status remains within the competence of EU Member States and within the margins of appreciation of the Convention for the Protection of Human Rights and Fundamental Freedoms (hereinafter: the Convention or ECRH) ${ }^{3}$ signatories.

Generally speaking, the acceptance of same-sex marriages and equality of same-sex couples' rights is high in Western and Northern European Member States, whilst it is the lowest in Central and Eastern European Member States. ${ }^{4}$ The reasons for divergences are numerous, starting from geographical location, complex history, socio-cultural values, social-democratic tendencies, legal tradition, religious features and political standpoints, whereas on the other hand there are personal motives of same-sex couples to live in non-formal or registered partnerships or in a marriage.

The Nordic Countries were the first in the world to incorporate same-sex relationships into the sphere of traditional family law. The legal development in this area is the trust in democratic processes and lack of challenges through the judiciary ${ }^{5}$,

2 About discussion of same-sex marriage debates within the EU as well as the US, see e.g. Bell, M. Holding Back the Tide? Cross-Border Recognition of Same-Sex Partnerships within the European Union, European Review of Private Law, vol. 12, no. 5, 2004, pp. 613-614

3 Convention for the Protection of Human Rights and Fundamental Freedoms, ETS No. 005, signed in Rome on 4 November 1950, and came into force on 3 September 1953

4 Special Eurobarometer 493, Discrimination in the EU in 2019 (publication October 2019), pp. 123124, https://data.europa.eu/euodp/en/data/dataset/S2251_91_4_493_ENG, Accessed 02.03.2020

$5 \quad$ Friðriksdóttir, H., The Nordic Model: Same-Sex Families in Love and Law, in: Gallo, D.; Paladini, L.; Pustorino, P., (eds.), Same-Sex Couples before National, Supranational and International Jurisdictions, 
while for example in Germany and Austria, a leading role was played by legislatures, but with the constitutional framework of the state setting the contexts for occasional judicial intervention, and a 'separate but equal' regime of a registered partnership rather than marriage for same-sex couples. The legal status of same-sex couples in Eastern European countries is to a large extent the result of an interplay between the courts and Parliaments in the recognition of same-sex couples within a legal system.

Until the late 1980s, there was no legal recognition of same-sex relationships in the European jurisdiction. ${ }^{6}$ Legal recognition of same-sex relationships in Europe began, as stated above, in the Nordic countries ${ }^{7}$. Denmark was the first state to introduce a registered partnership for same-sex couples in 1989. Soon other Nordic and other countries followed Denmark's lead, Sweden (1994), the Netherlands (1997), Spain (1998), Belgium (1999), France (1999), Portugal (2001), Germany (2001), Finland (2001), Luxembourg (2004), the United Kingdom (2004), Slovenia (2005), the Czech Republic (2006), Hungary (2009), Ireland (2010), Austria (2010), Croatia (2014), Malta (2014), Greece (2015), Cyprus (2015), Estonia (2016) and Italy (2016). ${ }^{8}$

The next step in the evolution of the same-sex relationship was the opening up to same-sex marriage. The Netherlands was the first state, which allowed same-sex marriage in 2001 and thus became the first state to depart from the traditional notion that only the persons of opposite sex may enter into marriage. Belgium (2003), Spain (2005), Sweden (2009), Portugal (2010), Denmark (2012), France

Heidelberg: Springer, 2013, p. 161

6 That changed to a large extent, due to the effort and persistence of many organizations and individuals. "In the European jurisdictions the broader legal recognition of same-sex relationship was generally brought through legislation, as a result of the efforts of organisations and political parties. By contrast, outside of Europe, litigation based on constitutional and human rights was more often the way legal recognition of same-sex couples was effected, e.g. in many US states. In European jurisdictions where the legislative route has not fostered progress and there is still no or incomplete recognition of same-sex couples, litigation based on national constitutions and the ECHR can, and presumably will, be utilised to bring about legal reform"; Scherpe, J., M., The Legal Recognition of Same-Sex Couples in Europe and the Role of the European Court of Human Rights, The Equal Rights Review, Vol. Ten, 2013, p. 83

7 By contrast, see cohabitation, Lucić, N.; Duić, D.; Muhvić, D., Izvanbračna zajednica: Analiza medunarodnih i europskih normi u svrhu stvaranja nacionalnih standarda, Zbornik radova Pravnog fakulteta u Nišu, 2020, p. 17

8 For an overview on the legal status of same-sex relationships, see e.g. Boele-Woelki, K.; Fuchs, A. (eds.), Legal Recognition of Same-Sex Relationships in Europe, 2nd ed., 2012; Wintemute, R.; Andenæs, M. (eds.), Legal Recognition of Same-Sex Partnerships - A Study of National, European and International Law, Hart Publishing, 2001 
(2013), the United Kingdom (2014), Luxembourg (2015), Ireland (2015), Finland (2017) and Germany (2017) followed its example. ${ }^{9}$

In many European countries, particularly in Eastern Europe e.g. Poland, Hungary, Bulgaria, Latvia, Lithuania, etc. (but also in Greece) there is a strong opposition to the legal recognition of same-sex relationships. Additionally, some of them in their Constitutions ${ }^{10}$ defined marriage as a union of a man and a woman. ${ }^{11}$

As regards the member states of the $\mathrm{CoE}$, twenty-eight out of forty-seven states so far have passed legislation that allows same-sex couples to have their relationship recognized. This lack of consensus among the member states of the CoE confirms that the states generally have a broad discretion as to whether marriages that are entered into abroad, are recognized as marriages. ${ }^{12}$

It could be concluded that Europe is not harmonized about this issue, although today it is one of the most progressive continents in terms of recognizing and legal regulation of same-sex relationships. Acceptance of same-sex relationships is high in Western and Northern European Member States and the difference is only in the form of the relationship whether it is a marriage, registered partnership or informal union ${ }^{13}$, whilst it is the lowest in Central and Eastern European Member States. There are six EU Member States i.e. Eastern EU Member States that still have not identified or recognized same-sex relationships in any way ${ }^{14}$, and five Member States ${ }^{15}$ (also Eastern EU Member States) that have constitutionally "banned" a same-sex marriage. ${ }^{16}$ However, the number of same-sex marriages and

$9 \quad$ Additionally, Canada, South Africa, Iceland and Argentina followed the Netherlands example and the states in the USA: Washington, D.C., Massachusetts, Connecticut, Iowa, Vermont, New Hampshire and New York as well as Mexico City, see: Latten, J.J.; Mulder, C.H.; Partner relationships in the Netherlands: new manifestations of the Second Demographic Transition, Genus, vol. 69, no. 3, 2013, p. 108

10 Rijpma J., J. You Gotta Let Love Move: ECJ 5 June 2018, Case C-673/16, Coman, Hamilton, Accept v Inspectoratul General pentru Imigrări, European Constitutional Law Review, vol.15, no. 2, 2019, p. 326

11 Digoix, M., Same-sex families and legal recognition in Europe, Cham: Springer, 2020, pp. 12-19

12 See the judgment Orlandi and Others v Italy (2017)

13 Scherpe, op.cit., note 6, pp. 85-86

14 Bulgaria, Latvia, Lithuania, Poland, Romania and Slovakia

15 Hungary, Latvia, Croatia, Lithuania and Slovakia, while Romania has included a provision to that effect in its Civil Code - Article 277(1) of the Romanian Civil Code

16 Tryfonidou, A., The EU Top Court Rules that Married Same-Sex Couples Can Move Freely Between EU Member States as "Spouses": Case C-673/16, Relu Adrian Coman, Robert Clabourn Hamilton, Asociatia Accept v Inspectoratul General pentru Imigrări, Ministerul Afacerilor Interne, Feminist Legal Studies, vol. 27, issue 2, 2019, p. 216; Khan, M. Europe's quiet new culture wars over LGBTI rights, Financial Times, 2018, available at: [www.ft.com/content/d027b3c8-f902-11e8-8b7c-6fa24bd5409c], accessed 30.03 .2020 
other forms of same-sex unions has been increasing and there are general trends towards their regulation and legalization.

\section{LEGAL PROTECTION OF SAME-SEX COUPLES IN SELECTED NATIONAL JURISDICTION IN BRIEF}

In the light of the above mentioned, the national legislators have developed different models of protection of same-sex couples. Regarding the level of recognition and formalization of same-sex relationships and protection of the rights of samesex couples, the European countries can be divided into several categories and these are: countries that allow same-sex couples to enter into marriage the same way as the heterosexual couples: Western and Nordic European countries, e.g. The Netherlands, Belgium, Spain, Sweden, Denmark, Germany, etc.; countries that recognize rights of same-sex couples in their laws and some of them allow registering their same-sex union as a registered partnership with the legal effect as almost the same as marriage: e.g. Croatia, Hungary; countries that recognize some rights of same-sex couples as a result of international and national court decisions: e.g. Poland and Romania, countries that passed the laws prohibiting discrimination with regard to sexual orientation in addition to the EU member and candidate states e.g.: Albania, Bosnia and Herzegovina, etc.

The development of favourable same-sex legislation within family law in the Nordic Countries is the fact that changes have been brought about through the democratic process. The Nordic Countries have gradually taken action to reduce exclusion of same-sex couples in family law, starting from the adoption of laws on registered partnership leading up to the acceptance of a gender-neutral marriage in all of the Countries except Finland.

Sweden ${ }^{17}$ allowed same-sex couples to register same-sex partnerships in 1994 through the Registered Partnership Act. ${ }^{18}$ The informal relationships of both opposite-sex and same-sex couples (couples living habitually together and sharing a joint household) who have not entered into marriage are governed by a Swedish Cohabitation Act (2003). The registration of the same-sex partnership before a competent authority was allowed for same-sex partners before it allowed them to enter into marriage in 2009. Once marriage became an available option for

17 Jänterä-Jareborg, M.; Brattström M.; Eriksson, L., Informal relationships - Sweden, National report: Sweden, 2015, p. 1, available at: [http://ceflonline.net/wp-content/uploads/Sweden-IR.pdf], Accessed 02.03.2020

18 In June 1994 the Swedish Parliament adopted Act No. 1117/1994 on registered partnership, Scherpe, op. cit., note 6, p. 171 
same-sex couples $(2009)^{19}$, there was no need for the Swedish model of registered partnership.

In 2001, the Netherlands was the first country in the world to legalize same-sex marriage. Prior to this, the possibility to register a partnership before the competent authority was introduced into Dutch legal system in 1998 for both same-sex and opposite-sex couples. There are almost no differences in legal effects between a marriage and a registered partnership ${ }^{20}$, so they differ mainly in the way they are established and terminated, whereas informal partnerships take less legal effects than those registered before a competent authority. ${ }^{21}$

In Germany, the traditional resistance toward same-sex marriage has not prevented the national legislators from adopting a regulation introducing same-sex registered partnerships. ${ }^{22}$ Germany is an example of a country that, respecting the form as a basis of legal certainty, refused to extend legal effects of formal unions such as marriage and registered partnership to informal partnerships. The German legislator provided for same-sex couples to enter into marriage in 2017. Previously, same-sex couples could enter into a registered partnership thus enjoying the same rights as spouses. The German registered partnership exclusively for same-sex couples was introduced in 2001, but originally there were some significant substantial differences in the legal consequences of marriage and the registered partnership. ${ }^{23}$ Many of those were challenged successfully, both politically and in the courts, particularly before the Federal Constitutional Court and the CJEU. According to German legislation, de facto partnership did not enjoy protection deriving from family law. The standpoint of the German legislator was that all heterosexual partners wishing to legally regulate their family relations can at any time enter into marriage, whereas same-sex partners can register their partnerships and that the free will of those who do not want it, should be respected. Having allowed all couples, regardless of their gender to enter into marriage, Germany abolished the

\footnotetext{
$19 \quad$ Ibid, p. 173

20 Schrama, W., National Report: The Netherlands, 2015, pp. 1-8, available at: [http://ceflonline.net/ wp-content/uploads/The-Netherlands-IR.pdf], accessed 01.04.2019

${ }^{21}$ In order for all partners to enjoy the same rights, the law provided for the possibility to alter the previously solemnized marriage into registered partnership. However, this legislative option was dismissed in March 2009 because it was often taken up by partners wishing to end the marriage more easily since the termination of a registered partnership was simpler than the termination of a marriage, and because similar option was not available in other jurisdictions, Latten; Mulder, op. cit., note 9, p. 110

22 Repetto, G., At the Crossroads Between Privacy and Community: The Legal Status of Same-Sex Couples in German, Austrian and Swiss Law, in: in Gallo, D.; Paladini, L.; Pustorino, P., (eds.), Same-Sex Couples before National, Supranational and International Jurisdictions, Heidelberg: Springer, 2014, p. 263

23 Ibid, p. 272
} 
institution of registered partnership, and has not extended the legal effects of marriage to de facto unions since then.

Hungary ${ }^{24}$ has recognized informal same-sex couples for several decades and since 1995 the definition of cohabitation has been changed in favour of same-sex couples by the decision of the Hungarian Constitutional Court. ${ }^{25}$ The aim of the Hungarian legislature was to allow the formal regulation of both same-sex and opposite-sex partnerships by their registration before a competent authority, which will guarantee their legal protection similar to spouses. However, this has never come to life in Hungary. The Constitutional Court of Hungary found the law unconstitutional even before it entered into force. ${ }^{26}$ It applied the reasoning that allowing not only same-sex but also opposite-sex partners to register their partnership would result in duplicating the institution of marriage and violating its special protection under the Constitution. Under the influence of these standpoints, the Hungarian legislator adopted a new act allowing only same-sex partners to formally register their partnership.

Romania, as mainly Orthodox and relatively conservative country, decriminalised homosexuality as late as 2001, after sustained international pressure. Romania does not provide same-sex couples with any form of legal recognition. The constitution of Romania, unlike the constitution of e.g. Bulgaria, Croatia, Latvia, Lithuania, contains a gender-neutral phrasing surrounding 'family' and the Romanian Civil Code does not only define marriage as the union of a man and a woman, but also stipulates that "marriage between persons of the same sex shall be prohibited" and, even more specifically, "marriages between persons of the same sex entered into or contracted abroad by Romanian citizens or by foreigners shall not be recognized in Romania". In 2016, the Citizens' Initiative "Coalition for the Family" collected three million signatures in support of the definition of marriage as a "union of a man and a woman" in the Romanian Constitution. In October 2018, the Romanians voted in favour of a referendum on marriage. More than 90 percent of voters voted in favour of the definition of marriage as a union between

24 Szeibert, O., National Report: Hungary, Informal relationships - Hungary, 2015, available at: [http:// ceflonline.net/wp-content/uploads/Hungary-IR.pdfl, accessed 01.04.2019

25 The Hungarian Constitutional Court held in decision No. 14/1995 that marriage was reserved for heterosexual relations, but it found that the exclusion of same-sex couples from common-law civil unions violates the principles of equal treatment and human dignity, see: Bodnar, A.; Śledzińska-Simon, A., Between Recognition and Homophobia: Same-Sex Couples in Eastern Europe, in: Gallo, D.; Paladini, L.; Pustorino, P., (eds.), Same-Sex Couples before National, Supranational and International Jurisdictions, Heidelberg: Springer, 2013, p. 227

26 Hungarian Constitutional court decision No. 32/2010, Ibid, p. 228 
a man and a woman. However, the threshold of 30 percent of the total number of voters was not reached, thus the referendum failed. ${ }^{27}$

Accordingly, the fact that Europe is not unique about the legal recognition of same-sex relationship and protection of same-sex couples has been accounted for in only a few selected national jurisdictions and in support of the argument that there are still diverging views in each Member State.

\subsection{LEGAL PROTECTION OF SAME-SEX COUPLES IN THE REPUBLIC OF CROATIA}

The prohibition of discrimination based on sexual orientation is protected by Article 14 of the Constitution ${ }^{28}$ of the Republic of Croatia (hereinafter: the Constitution). ${ }^{29}$ In addition to the Constitution, the rights of persons of same-sex orientation are protected by the laws of the Republic of Croatia that comprise non-discrimination provisions concerning sexual orientation, such as the Gender Equality $\mathrm{Act}^{30}$, the Anti-Discrimination $\mathrm{Act}^{31}$, etc.

Currently, family law protection of life partnerships of partners of different sex (spouses and cohabitees) and same-sex (life partners and informal life partners) in Croatia is governed by two separate laws i.e. the Family Law ${ }^{32}$ and the Same-sex Life Partnership Act. ${ }^{33}$ Regardless of which of the four family law institutions provided by these laws, the partners decide to live in, they shall enjoy exactly the same legal effects, so that after three years of living together, the partners of different sexes (cohabitees) according to the Croatian law enjoy the same rights and duties as spouses. The informal life partners shall enjoy all rights and have duties as life partners who solemnized their life partnership before a competent authority.

\footnotetext{
27 See: [https://narod.hr/eu/referendum-o-braku-u-rumunjskoj-90-posto-biraca-podrzava-brak-kao-zajednicu-jednog-muskarca-i-jedne-zene], and Cojocariu, C., Same-Sex Marriage before the Courts and before the People: The Story of a Tumultuous Year for LGBT Rights in Romania, Verfassungsblog, 25 January 2017, available at: [https://verfassungsblog.de/same-sex-marriage-before-thecourts-and-beforethe-people-the-story-of-a-tumultuous-year-for-lgbt-rights-in-romania], accessed 02.10.2019

28 Constitution of the Republic of Croatia, Official Gazette Nos. 56/90, 135/97, 113/00, 28/01, 76/10 and $5 / 14$

29 Also see Articles 3 and 35 of the Constitution

30 Gender Equality Act, Official Gazette, Nos. 82/2008 and 69/2017

31 Anti-discrimination Act, Official Gazette Nos. 85/08 and 112/12

32 Family law, Official Gazette, Nos. 103/15 and 98/19

33 Same-sex Life Partnership Act, Official Gazette Nos. 92/2014 and 98/19
} 
Previously, relationship between same-sex partners in the Republic of Croatia was governed for the first time by the Same-Sex Union Act, ${ }^{34}$ under which same-sex partners were only able to enter into a de facto partnership, which could produce certain legal effects, but were not given the opportunity to enter into marriage or formally establish same-sex partnership. ${ }^{35}$

On 1 December 2013, the first national referendum on the definition of marriage to amend the Constitution was held whereby the definition of marriage as a life union between a man and a woman would be introduced into the Constitution. ${ }^{36}$ As a result of the referendum, the Constitution "banned" same-sex marriages. In its Communication on the Citizens' Constitutional Referendum on the Definition of Marriage, the Constitutional Court gave an opinion on the definition of marriage as a union between a man and a woman, in which it clearly stated that "it is relevant from the point of view of substantive law that marriage, cohabitation, and same-sex partnership are legally recognized in the Republic of Croatia, and that the Croatian law of today is in line with European legal standards regarding institutions of marriage and family life". ${ }^{37}$

In 2014 in response to the Constitutional amendment, the Same-sex Life Partnership Act, which recognizes both a life partnership ${ }^{38}$ and an informal life partnership, was adopted. The existence of an informal life partnership is demonstrated in the same manner and under the same requirements as cohabitation. ${ }^{39}$ Under the Same-

34 Same-Sex Union Act, Official Gazette No. 116/2003

35 The Same-Sex Union Act regulated a very small scope of rights (the right to maintenance and property relations), which did not form the basis for a normal and equal life as recognized for the persons of different sex. This was confirmed in practice, as no same-sex union has officially been registered, Petrašević, T.; Duić, D.; Buljan, E., Prava istospolnih zajednica u Europskoj Uniji s posebnim osvrtom na Republiku Hrvatsku, Strani Pravni život, vol. 61, no. 3, 2017, p. 157

36 The initiator was the association "On behalf of the family" which aimed at transposing a definition from the Family Law defining marriage as a union of a woman and a man into the Constitution. Due to the number of collected signatures $(749,316.00)$, the Croatian Parliament voted to call a referendum on the definition of marriage. There were $37.89 \%$ voters that took part in the referendum, out of which $67.75 \%$ voted in favour and $33.63 \%$ against it

37 Communication on the Citizens' Constitutional Referendum on the Definition of Marriage No.: SuS-1/2013, 14.11.2013, Official Gazette No. 138/2013. In the Communication, the Constitutional Court of the Republic of Croatia stated also, inter alia, clearly and unambiguously as follows: “... Any possible amendment to the Constitution by the provision that marriage is a life union of a woman and a man shall not affect further development of the legal framework of cohabitation and same-sex union institutions in accordance with the constitutional requirement that every person in the Republic of Croatia has the right to respect and legal protection of their private and family life and human dignity."

38 A life partnership is a family life relationship between two persons of the same sex, concluded before a competent authority, pursuant to the provisions of this Act

39 The informal life partnership is a family life relationship between two persons of the same sex who have not concluded a life partnership before a competent authority, provided the relationship has lasted no 
sex Life Partnership Act, same-sex life partners have the right to respect for family life, as well as all the effects of a marriage, except the right to adopt children. ${ }^{40}$

The Republic of Croatia is an example of a state in which the international and national courts played a crucial role in the legal recognition of rights of samesex couples and the accession to the $\mathrm{CoE}$ and the EU contributed to progress in achieving the standard of protection against discrimination with regard to sexual orientation. Nevertheless, the Republic of the Croatia is among the relatively few European countries that have changed their constitutions to the effect that marriage is only possible between a man and a woman, thus precluding samesex marriages. The Croatian national legislation has in response shown definitely progressive in its view to grant equal rights to same-sex partnership, making them equal to marriage, except in child adoption issues and it extended the rights of formalized same-sex life partnerships to same-sex informal partnerships. ${ }^{41}$ However, there are a number of aspects in which same-sex couples lead to disputes. ${ }^{42}$

\section{LEGAL PROTECTION OF SAME-SEX COUPLES AND THEIR RIGHTS UNDER COE AND EU LAW}

It must be noted that the Convention and the Charter of Fundamental Rights of the EU (hereinafter: the EU Charter) ${ }^{43}$ contain corresponding rights, and these rights have in principle the same meaning and scope. ${ }^{44}$ The right to private and family life ${ }^{45}$, the right to marry and to found a family ${ }^{46}$ the right to respect for

less than three years and from its beginning has met the requirements prescribed for the validity of a life partnership. More about informal relationships see: Lucić; Duić; Muhvić, op.cit., note 7, pp. 2122 and Lucić, N., Pravno uredenje braka i drugih oblika životnih zajednica, in: Rešetar B. et al. (eds.), Suvremeno obiteljsko pravo i postupak, Osijek: Pravni fakultet Osijek, 2017, p. 70

40 The institution of child adoption should be distinguished from the possibility of providing a public foster care service, which was as one of the main objections to the requests and proposals, among others, of same-sex partners and the LGBT community, submitted to the Constitutional Court in abstract control - the proposals to institute proceedings to review conformity with the Constitution of Articles 9, point 3, 11(3) and 13(2) of the Foster Care Act, Official Gazette, No. 115/2018; Decision No. U-I$144 / 2019$ and others of 29 January 2020

41 About critical review of legal uncertainty in equal treatment of formal (marriage and life partnership) and informal (cohabitation and informal life partnership) life unions see: Rešetar, B., Uvod-odrednice novog obiteljskog prava i postupka, in: Rešetar, B. et.al.(eds.), Suvremeno obiteljsko pravo i postupak, Osijek: Pravni fakultet Osijek, 2017, p. 16 and pp. 84-86; 95-97

42 See note 40

43 Charter of Fundamental Rights of the European Union, OJ C 326, 26.10.2012

44 However, this does not prevent EU law from granting more protection - Article 52 (3) of the EU Charter

45 Article 8 of the Convention and Article 7 of the EU Charter

46 Article 12 of the Convention and Article 9 of the EU Charter 
family life $e^{47}$, the prohibition on discrimination ${ }^{48}$ and the right to human dignity. ${ }^{49}$ Both the ECRH and the EU Charter provide that the right to marry and to found a family is guaranteed in accordance with national laws governing the exercise of this right.

As already mentioned, in cases where same-sex couples were legally recognised on a broader scale, in Europe this generally happened through legislation rather than litigation. The litigants often relied on non-discrimination and equality provisions in national constitutions, but also on Convention provisions, Articles 8 and 14 of the Convention. In this context, the paper deals exclusively with these rights of the Convention that correspond with Article 7 and 21 of the EU Charter.

Although the Convention and the Charter of the EU contain corresponding rights, it is interesting to note that in the European jurisdiction the broader legal recognition of the right to respect for family life in EU law differs significantly from the right laid down in Article 8 of the Convention and the practice of the ECtHR. Article 8 of the Convention does not guarantee the right to family reunification by itself but imposes the minimum protection that must be provided by the State. In this context the paper, in EU scope regarding implications for the internal market, also deals with right to family reunification.

The right to family reunification ${ }^{50}$ has been one of the main sources of migration in the EU for the last twenty years. ${ }^{51}$ However, one should distinguish between the

47 Article 8 of the Convention and Article 7 of the EU Charter

48 Article 14 of the Convention and Article 21 of the EU Charter and the recital 31 of the Directive 2004/38/EC of the European Parliament and of the Council of 29 April 2004 on the right of citizens of the Union and their family members to move and reside freely within the territory of the Member States amending Regulation (EEC) No 1612/68 and repealing Directives 64/221/EEC, 68/360/EEC, 72/194/EEC, 73/148/EEC, 75/34/EEC, 75/35/EEC, 90/364/EEC, 90/365/EEC and 93/96/EEC, OJ L 158

49. Article 1 of the EU Charter

50 The freedom of movement of persons is one of four fundamental freedoms of EU law. It is recognized to EU citizens and their family members and to some extent, to third country nationals. It was originally introduced for economic reasons, to allow workers to move freely where there is a shortage of labour in their qualifications. However, in practice it did not live up to expectations due to language and cultural barriers, but also because the decision to move to another Member State was influenced by (in)ability to take the family. Thus, the family appeared as a barrier to mobility of workers, see: Petrašević, T., Pravo na spajanje obitelji u EU, in: Župan, M. et.al.(eds.), Prekogranično kretanje djece u Europskoj uniji, monografija, Osijek, 2019, p. 100; Barnard, C., The Substantive Law of the EU, The Four Freedoms, Third edition, Oxford University Press, 2011, p. 265

51 See European Commission Press Corner: Press release 28 March 2006, Europeans move for love and a better quality of life, [https://ec.europa.eu/commission/presscorner/detail/en/IP_06_389]; 25 November 2013, also see Free movement of people: five actions to benefit citizens, growth and employment in the EU, [https://ec.europa.eu/commission/presscorner/detail/en/IP_13_1151] and 15 January 2014, 
right to family reunification of EU citizens and their family members irrespective of their nationality on one hand and the right of third-country nationals to family reunification on other. ${ }^{52}$ The right of the Union citizens to move freely is stipulated by Article 21 Treaty on the Functioning of the EU (hereinafter: TFEU) ${ }^{53}$ and further developed in secondary legislation - Directive 2004/38/EC ${ }^{54}$ (hereinafter: Directive 2004/38/EC or Citizens' Rights Directive). ${ }^{55}$ The Citizens' Rights Directive does not provide a definition of the term "spouse" in one way or another but contains a neutral provision leaving the interpretation of the meaning "open". Before the final versions of Directive 2004/38/EC, the Commission advocated restricting the term "spouse" to persons of different sex, Parliament was in favour of defining the term as "neutral" and the Council was neither willing to explicitly refer to the term "spouse" as a same-sex partner, nor to explicitly exclude it. Therefore, the final text of Directive 2004/38/EC refers simply to "spouse". ${ }^{56}$

Every EU citizen has the right to move freely within the territory of the Member States for the period not exceeding three months, with a valid travel document an identity card or a passport. For a stay exceeding three months, in accordance with Article 7 of Directive 2004/38/EC, a Union citizen must have a special status. A continuous legal residence of at least five years entitles Union citizens and their family members to permanent residence. In accordance with the relevant EU regulations a Union citizen can be joined by his/her family members regardless of the category the citizen belongs to. ${ }^{57}$ The concept of a family, and thus the circle of persons who can join a Union citizen in the host Member State has expanded over

European Commission upholds free movement of people: [https://ec.europa.eu/commission/presscorner/ detail/en/MEMO_14_9], accessed 29.02.2020

52 Among EU citizens there are those who have made use of the free movement i.e. - dynamic citizens involving a cross-border element and then those who have not made any use of the freedom of movement, - static EU citizens, see Petrašević, op.cit., note 50, p. 95

53 Treaty on Functioning of the European Union (Consolidated version 2016), OJ C 202, 07.06.2016

54 Directive 2004/38/EC, which grants residence rights to Union citizens and their family members when they move to or reside in a Member State other than that of which they are nationals and these rights are crucial for third-country nationals as their residence rights in the EU are derived from their status as family members of Union citizens

55 See Communication from the Commission to the European Parliament and the Council on guidance for better transposition and application of Directive 2004/38/EC on the right of citizens of the Union and their family members to move and reside freely within the territory of the Member States; [https://eurlex.europa.eu/LexUriServ/LexUriServ.do?uri=COM:2009:0313:FIN:EN:PDF], accessed 01.10.2019.

56 Bačić Selanec; Bell, op. cit., note 1., p. 658, also see: Rijpma, J.; Koffeman, N., Free Movement Rights for Same-Sex Couples Under EU Law: What Role to Play for the CJEU?, in: Gallo, D.; Paladini, L.; Pustorino, P., (eds.), Same-Sex Couples before National, Supranational and International Jurisdictions, Heidelberg: Springer, 2013, pp. 465-475

57 Article 16(1) Directive 2004/38/EC 
time. Family members who must be admitted are defined in Article 2 of the Directive. This includes the spouse ${ }^{58}$ and the registered $\operatorname{partner}^{59}$, to the extent the home and host member state consider registered partnership the equivalent of marriage.

The answer to the question whether or not the measure violates Article 8 of the Convention differs on a case-by-case basis as it leaves a wide discretion to States, in contrast to which EU provisions on free movement and citizenship are very clear and precise with no room for discretion. ${ }^{60}$ This shall be supported by case-law analysis in following paragraphs of the paper.

\section{COURTS' CASE LAW}

\subsection{THE CJEU CASE LAW}

The CJEU has a progressive approach towards family law, especially when it has implications for the internal market, human rights, dignity, equality and non-discrimination. ${ }^{61}$ The same-sex couples who find themselves within the scope of EU law (whether EU citizens or not) must be able to rely on the protection of their fundamental rights, including the right to respect for family life. When exercising their rights of free movement, the same-sex couples may encounter the obstacles deriving from a lack of recognition of their relationships and arising mainly in areas of the law in which different-sex spouses traditionally enjoy certain benefits. Consequently, the CJEU case-law needs to provide an adequate answer to solve complex issues and to make a framework of cross-border movement of same-sex couples. The cases on the rights of same-sex couples have tended to reach the CJEU mostly as staff cases or preliminary references in the field of equal treatment in employment and occupation. ${ }^{62}$

58 Article 2(2) (a) of Directive 2004/38/EC

59 Article 2(2) (b) of Directive 2004/38/EC

60 However, in the cases: C-60/00 Mary Carpenter v Secretary of State for the Home Department, [2002], C-459/99 Mouvement contre le racisme, l'antisémitisme et la xénophobie ASBL (MRAX) v Belgian State, [2002] , C-291/05 Minister voor Vreemdelingenzaken en Integratie v R. N. G. Eind, [2007], Metock and other, the CJEU found that right to family life, as guaranteed by Article 8 of the Convention, was one of the fundamental rights guaranteed in the EU legal order (Article 7 of the EU Charter)

${ }^{61}$ More about legislative and judicial competence in matters related to family law, see Bačić Selanec; Bell, op.cit., note 1, pp. 659-661

62 In contrast to restrictive Treaty provisions on cross-border family legislation and the static progress of the EU legislator, See e.g.: Case C-249/96, Lisa Jacqueline Grant v. South-West Trains Ltd., [1998]; Joined Cases C-122/99 P and C-125/99 P D and Kingdom of Sweden v Council of the European Union, [2001]; Case C-267/06, Tadao Maruko v. Versorgungsanstalt der deutschen Bühnen, [2008]; Case C-147/08 Jürgen Römer v. Freie und Hansestadt Hamburg, [2011]; Case C-267/12 Frédéric 
The first case in which the CJEU encountered unfavourable treatment of persons of same-sex orientation and same-sex couples was the Grant case $(1998)^{63}$. The Court ruled that the refusal of travel allowances for Mrs Grant's same-sex partner had not constituted discrimination based on sex orientation, and that stable relationships between same-sex couples were not equalled with marriage or stable cohabitation of persons of opposite sex.

In 2001, in case D. and the Kingdom of Sweden ${ }^{64}$, the CJEU faced the issue of gender discrimination. Although Sweden provided at that time equal treatment for registered same-sex partners as well as for spouses, the Council of the EU dismissed the appeal and stated that the provisions of Regulation 781/98 could not be interpreted as treating same-sex registered partnership as equivalent to marriage. The CJEU maintained the standing taken in Grant case, concluding that the present case does not constitute discrimination, despite the fact that the Member State in which the same-sex partnership was registered recognized the institution the status equal to marriage. The CJEU found that it was not the partner's gender that determined whether there were grounds for obtaining a household allowance under the Regulation, irrespective of their sexual orientation and that the intention of the legislator in this case was not to grant household allowances to registered partners.

The most direct case law on the rights of same-sex couples is found in the following three cases of Maruko, ${ }^{65}$ Römer $^{66}$ and $\mathrm{Hay}^{67}$. All three cases concerned the availability of employment benefits under the Equal Treatment Directive ${ }^{68}$ to homosexual couples in registered same-sex partnerships where they were available to heterosexual married couples. The CJEU in Maruko took a different view and found discrimination on the grounds of sexual orientation ${ }^{69}$ and ruled that denying that a person, whose same-sex partner had died, was entitled to survivor's benefit paid on the same conditions as a surviving spouse was direct discrimination on grounds of that person's sexual orientation. It explicitly acknowledged that the

Hay v. Crédit agricole mutuel de Charente-Maritime et des Deux-Sèvres, [2013], Case C-443/15, David L. Parris v Trinity College Dublin and Others [2016], etc

63 See note 62

64 See note 62

65 See note 62

66 See note 62

${ }_{67}$ See note 62; Decision in the case Hay was passed a few weeks after the ECtHR judgment Vallianatos and Others v. Greece (2013) and was the answer to the ECtHR judgment

68 Directive 2000/78 establishing a general framework for equal treatment in employment and occupation [2000] OJ L303/16

69 The case Maruko is important in the context of the division of competences between the EU and the Member States, as well as regarding the distinction between direct and indirect discrimination even beyond the field of discrimination on grounds of sexual orientation 
area of family law falls within the exclusive regulatory competence of the Member States, but pointed out that in exercising that competence the Member States must comply with EU law and, in particular, with the provisions relating to the principle of non-discrimination.

In Römer case, the CJEU takes a step further, finding that denying access to a tax benefit entitlements to pension amount to persons in a registered same-sex partnership constitutes discrimination based on sexual orientation, if the same benefit is granted under same conditions to spouses. The CJEU points out that EU law depends on the Member States legislature, but since the laws of Member States can significantly discriminate the rights of persons of same-sex orientation, it must therefore be careful and play an active role in preventing any discrimination against same-sex partnerships. In Maruko and Römer cases, the final assessment of the comparability of the civil status of traditional marriages and registered partnerships was left to national courts of Member States. ${ }^{70}$ However, the CJEU did conduct such an analysis in Hay case.

In Hay case the CJEU faces the question of whether an employer's practice according to which employees who entered into marriage have the right to be awarded days of special leave and a salary bonus constitutes discrimination on the basis of sexual orientation, since this is not granted to persons of same-sex orientation. At the end of the reasoning, the Court pointed out that adverse treatment based on marital status, rather than on direct sexual orientation, is still direct discrimination, since homosexual couples cannot contract marriage under national law. ${ }^{71}$

In long-awaited decision in Coman case $^{72}$, the CJEU was given the opportunity to decide for the first time on the term 'spouse' in the context of Directive 2004/38/ EC related to a marriage contracted between two persons of the same sex. The CJEU clarified that the gender-neutral term 'spouse' in Article 2(2)(a) of the Directive 2004/38 implies that married same-sex couples enjoy free movement rights equal

70 Maruko (C-267/06) para. 72 and Römer (C-147/08) para. 52

${ }^{71}$ Selanec, G., Praksa evropskih i američkih sudova u oblasti pravne regulacije životnih zajednica osoba istog spola, in Petrić, N., et.al. (eds.), Izvan zakona: Pravna regulacija životnih zajednica parova istog spola u Bosni i Hercegovini, Sarajevo: Sarajevski otvoreni centar, 2016, pp. 111-112

72 Case C-673/16 Relu Adrian Coman and Others v. Inspectoratul General pentru Imigrări and Ministerul Afacerilor Interne, [2018], ECLI:EU:C:2018:385; The question put before the CJEU in Coman case has been a topic of much academic debate, see e.g. Bell, op. cit., note 2; Bell; Bačić Selanac, op. cit., note 1; Tryfonidou, op. cit., note 16; Rijpma, op. cit., note 10; Rijpma; Koffeman, op. cit., note 56; Kochenov, D. On Options of Citizens and Moral Choices of States: Gays and European Federalism, Fordham International Law Journal, vol. 33, no. 1, 2009, pp. 156-205, available at: [https://ssrn. com/abstract=1557955]; Toner, H., Migration rights and same-sex couples in EU law: a case study, in: Boele-Woelki, K.; Fuchs, A. (eds.), Legal Recognition of Partnerships in Europe, Intersentia 2012, pp. 285-308, etc 
to heterosexual married couples in the EU, regardless of how each particular Member State frames 'family' in its own legislation. The case involves a same-sex couple, Mr. Coman, a Romanian and US citizen, and Mr Hamilton, an American citizen, who met in New York in June 2002 and lived together for four years. Mr. Coman then moved to Brussels to work for the European Parliament while Mr Hamilton remained living in New York. They married in Brussels in November 2010, and in March 2012 Mr. Coman stopped working for Parliament and continued to live in Brussels, where he was entitled to unemployment benefits until January 2013. Following several years spent in a long-distance relationship, Coman and Hamilton decided to settle in Romania, and Mr. Coman applied for a residence-permit for his American husband based on the family reunification clause of Directive 2004/38.

The Romanian authorities refused to abide by the Directive, explaining their decision by non-recognition of "homosexual unions" in Romania. Supported by the reputable LGBT organization, the couple appealed the decision of the Romanian authorities. When their case reached the Constitutional Court of Romania, the court decided to stay the proceedings and submitted a preliminary reference to the CJEU to clarify the conditions under which Mr. Hamilton may be granted the right to reside in Romania for more than three months.

The CJEU established that it is apparent from a textual, systematic and teleological interpretation of the provisions of the Directive that it prescribes only the conditions for the entry and residence of a Union citizen in Member States other than the Member State whose national he is and does not allow the exercise of a derived right of residence for the benefit of third-country nationals, family members of a Union citizen in the Member State of which that Union citizen is a national. However, in certain situations third-country nationals who are family members of a Union citizen and who by virtue of the Directive are not granted derived right of residence in a Member State of which that citizen is a national, may be granted that right pursuant to Article 21(1) TFEU. The CJEU clarified that the gender neutral framing of 'spouse' in Article 2(2) (a) of the Directive 2004/38 implies that married same-sex couples enjoy free movement rights equally to heterosexual married couples in EU, regardless of how each Member State defines a 'family' in its own legislation.

Following the Coman ruling, the Romanian Constitutional Court $^{73}$ rendered a decision No. $534 / 2018^{74}$, stating, inter alia, that in addition to a few other EU

73 The Romanian Constitutional Court was confronted with the question of sexual orientation twice before the Coman case; [https://blogs.eui.eu/constitutionalism-politics-working-group/paying-lip-service-cjeu-unsurprising-decision-constitutional-court-romania-coman-case/], accessed, 04.01.2020

74 Decision of the Constitutional Court of Romania, No 534/2018 on the exception of unconstitutionality of the provisions of Article 277 (2) and (4) of the Civil Code was rendered with majority of votes, 
Member States, Romania has not legally regulated same-sex unions in any way. Acting in the "spirit" 75 of the CJEU ruling, the Romanian Constitutional Court declared the said provisions constitutional, but only to the extent of freedom of movement and residence in Romania, noting that it did not recognize same-sex unions in Romania by such a decision. However, the Coman case and the decision of the Romanian Constitutional Court faced sharp criticism, especially in Romania. ${ }^{76}$ Although most people considered the CJEU judgment exclusively as focusing on the freedom of movement of persons within the Union, some ${ }^{77}$ considered it a redefinition of the term "spouse", by which the CJEU called into question the competence of the Member States. ${ }^{78}$

With its ruling in the Coman case $^{79}$, the CJEU has provided legal certainty for married same-sex couples regarding their rights of free movement under EU law, especially because it requires the recognition of same-sex spouses as "spouses" rather than "partners" and that is crucial to ensure effective enjoyment by union citizens of free movement rights, and to prevent discrimination on the basis of sexual orientation and to ensure respect for their family life. Failure to recognize same-sex marriage by Member States that do not regulate same-sex marriage under national law would result in failure to recognize the right to family reunification of EU citizens, which then would limit the freedom of movement for Union citizens. ${ }^{80}$

with two dissenting opinions, the access to the decision in the English language is available on the site of the Judicial Network of the EU, [https://curia.europa.eu/rjue/upload/docs/application/pdf/201903/decro2018071801en.pdf], accessed 01.10.2019

75 In the Communication of July 2018, before the decision was announced, the Romanian Constitutional Court President Valer Dorneanu had made a public statement and given a brief reasoning of the decision pointing out that it had been made in the "spirit" of the CJEU Coman ruling that recognizes same-sex marriage in Romania for the purposes of freedom of movement of EU citizens, and revealed that the Romanian Constitutional Court had not conferred "more" rights for persons of same-sex orientation, but only fulfilled the minimum of the required rights, op.cit., note 74

76 [http://www.europeandignitywatch.org/disturbing-decision-by-the-eu-court-of-justice-redefines-theterm-spouses/], accessed 01.10.2019

77 Adina Portar, who is a Romanian lawyer working as a legal advisor with the ADF International in Brussels and who on behalf of the ADF International submitted an amicable report to the Romanian Constitutional Court requesting an approval for the organisation of the referendum vote

78 See: [https://www.nytimes.com/2018/06/05/world/europe/romania-ecj-gay-marriage.html], accessed 01.10 .2019

79 It is interesting to note that the government of the Netherlands, the first member state to open up civil marriage to same-sex couples, was the only member state to intervene, along with the European Commission, on the side of $\mathrm{Mr}$ Coman

80 It outlines the US Supreme Court decision in case Obergefell v. Hodges, 576 U.S. (2015), which was passed just one year before the Coman ruling and has greatly influenced the development of protection for same-sex unions outside the US, especially in EU Member States. The Supreme Court of the US held that the XIV Amendment of the US Constitution required every State to legalise same-sex marriage and to recognize same-sex marriages lawfully conducted in other States. The US Supreme 
In order to avoid the consequences of the decision, some Member States will attempt (or they already have) to prohibit same-sex marriage by their Constitution. However, the prohibition of same-sex marriage will not protect Member States from the consequences of the Coman ruling, since the supremacy of EU law also outweighs the constitutional provisions of Member States, in the event of conflict between the law of Member States and EU law.

It is noticeable that the CJEU in the Coman ruling resolved the issue primarily within the framework of the free movement of persons rather than as a fundamental right issue. Additionally, the judgment left a number of important questions open, e.g. recognizing same-sex marriage in other legal matters (inheritance, survivor pension, hospital visits, etc. ${ }^{81}$ ) or in situations when marriage is legally concluded outside the EU, and the CJEU also faced the issue of the obligation of mutual recognition of same-sex marriages entered into in accordance with applicable legislation in EU Member States, but not with the issue of same-sex (registered) partnership. ${ }^{82}$

The CJEU plays a significant role in the application of the principle of free movement of persons and the prohibition of sexual orientation discrimination. CJEU's case law and its landmark judgements on this topic show significant changes in its view. That progress shows a consistent and non-discriminatory application to EU citizens, irrespective of their sexual orientation. The Coman case gave an answer to important questions, although for the time being just for same-sex marriage recognition for immigration purposes in the EU, but also made the leads to the further development of equality and non-discrimination law in Europe.

Court ruled with five votes in favour and four votes against the decision that federal states cannot ban marriage licenses for same-sex couples. This made all bans on same-sex marriages in any US state or territory invalid and same-sex marriage became legal at federal level. This meant that marriage had to be redefined in all US states and contracting same-sex marriage had to be made legal, thus deciding that a ban on same-sex marriage was a violation of the US Constitution. In this way, the duty to redefine marriage was imposed on all US states, including those that defined marriage at the level of their legislation as a union of one woman and one man. This decision was preceded by important decisions - Hillary Goodridge and Others v. Department of Public Health, 798 N.E.2d 941 (Mass. 2003) and Hollingsworth v. Perry 570 U.S. (2013)

81 Tryfonidou, A., An analysis of the ECJ ruling in Case C-673/16 Coman, The right of same-sex spouses under EU law to move freely between EU member states, research report for NELFA, 2019, pp. 1314, available at: [http://nelfa.org/inprogress/wp-content/uploads/2019/01/NELFA-Tryfonidou-report-Coman-final-NEW.pdf], accessed 29.02.2020

82 See Case C-89/17 Secretary of State for the Home Department v. Rozanne Banger, [2018] 


\subsection{THE ECtHR CASE-LAW}

For decades, the ECtHR has consistently held that marriage is exclusively a union of a man and a woman. Having recognized the changes in social development and political changes, the ECtHR responded with a change in doctrine. ${ }^{83}$ The ability for same-sex couples to secure protection is set under Article 8 (right for private and family life), Article 12 (right to marry) and Article 14 (right to non-discrimination) of the Convention

In the landmark case Karner v. Austria ${ }^{84}$, the ECtHR was confronted with the question of whether it amounted to discrimination, if national legislation that allows heterosexual partners in stable emotional relationship to rent an apartment and in the event of death of the tenant, his/her companion has the possibility of renting it, does not provide the same for stable emotional relationship of persons of the same sex. Considering that the State failed to prove that there was any reason to justify the difference in treatment as necessary for the protection of an important interest, the ECtHR found a violation of Article 8 of the Convention.

In Burden v. UK ${ }^{85}$, two sisters lived together for thirty-one years. They jointly owned property and each left a part of the property by will to the other. In the event of the death of one of them, due to the estate value exceeding the established threshold, the surviving sister had to pay inheritance tax. They pointed out the discriminatory interference with their property rights since married partners and same-sex partners were exempt from inheritance tax. The ECtHR found that the relationship between siblings is qualitatively of a different nature to that between married couples and homosexual civil partners under the United Kingdom's Civil Partnership Act. Marriage and same-sex partnership are considered special relationships that are entered into voluntarily and thoughtfully resulting in contractual rights and obligations. Since the applicants were in blood relationship, it was a completely different issue. ${ }^{86}$

83 See judgement Christine Goodwin v. UK (2002); the case involved the possibility of transgender persons to adjust their official documents with the fact of gender change so that they could enter into marriage. The ECtHR acknowledged that, in the face of developments in the Member States, it has changed its established position on the exclusive heterosexual nature of marriage and similar family unions and established violation of Articles 8 and 12 of the Convention. Following the Goodwin ruling, in 2004, the United Kingdom introduced a regulation requiring transgender persons to request an official gender recognition certificate

${ }^{84}$ See judgment Karner v. Austria (2003)

85 See judgment Burden v. UK (2008)

86 See also the more recent interesting judgment Ratzenböck and Seydl v. Austria (2017) 
The most important step in the development of the ECtHR case law is the judgment Schalk and Kopf v. Austria ${ }^{87}$, which brought same-sex relationship within the scope of family life. The Court ruled that cohabiting same-sex couples living in a stable de facto partnership enjoy not only the right to respect for their private life, but also the right to respect for their family life. Mr. Schalk and Mr Kopf who lived in a stable emotional de facto partnership claimed that they were discriminated on the basis of their sexual orientation with regard to the protection of right guaranteed by Articles 8, 12 and 14 of the Convention, because they were denied the opportunity to marry or have their relationship otherwise recognised by law in Austria. During the dispute, the Registered Partnership Act was introduced, which granted their partnership legal recognition. This allowed the ECtHR "not to refer" to the applicant's complaint. The decision essentially obliges contracting states to provide at least some form of legal framework, some form of legal recognition for same-sex couples and their family life. ${ }^{88}$

In its judgment in Xv. Austria ${ }^{89}$ and decision Boeckel v. Germany ${ }^{90}$, the ECtHR held that same-sex couples entering into a partnership must have access to adoption to the same extent granted to respective heterosexual partnership, which means that same-sex partnerships in which partners raise a child together represent the union of family life referred to in Article 8 of the Convention.

The case of Vallianatos et al. v. Greece ${ }^{91}$ argues that the fact that the Greek registered partnership is open only to couples of the opposite sex amounts to a violation of family life (Article 8) and non-discrimination (Article 14). The ECtHR found a violation of Article 8 of the Convention to applicants who lived in a stable emotional same-sex relationship, given that the State did not provide them with the minimum legal recognition that is provided to (civil) partnership of heterosexual couples. The Court established that same-sex partnerships were as capable as heterosexual partnerships of entering into stable committed relationships, and those same-sex couples sharing their lives had the same needs as heterosexual couples in terms of mutual support and assistance. The fact that the State did not legally recognize same-sex partnership is a violation of their dignity, since they have the same right to the same respect as heterosexual partnership. The ECtHR rejected the Greek government argument that the legal recognition of status of civil part-

\footnotetext{
$87 \quad$ See judgment Schalk and Kopf v. Austria (2010)

88 See also judgment P.B. and J.S. v. Austria (2010)

$89 \quad$ See judgment $X v$. Austria (2013)

90 See decision Sabine Boeckel and Anja Gessner-Boeckel v. Germany (2013)

$91 \quad$ See note 67
} 
nership was limited to heterosexual couples for the protection of families in the traditional sense. ${ }^{92}$

Following the Vallianatos case, the ECtHR clearly indicated to the Convention seeking to ensure a kind of legal recognition of stable emotional same-sex partnerships.

Shortly after the US Supreme Court ruled in Obergefell ${ }^{3}$, the ECtHR ruled in Oliari and Others $v$. Italy, ${ }^{94}$ in which the mere fact that the state did not secure legal recognition of the status of stable same-sex partnerships as a union generating adequate scope of rights and obligations is a violation of their dignity. The ECtHR found that the refusal to recognize same-sex marriage solemnized abroad constitutes a violation of the right to family life and that Italy should introduce a possibility to regulate same-sex partnerships. The ECtHR's interest in the fact that the EU legal order has clearly departed from the traditional family concept, both through the provisions of the Charter and through the fact that most EU Member States have legalized either equality to marriage or a partnership of persons of the same sex. ${ }^{95}$

The Oliari case was primarily concerned with the lack of any legal protection for same-sex couples in Italy, including civil unions.However in Orlandi and Others v. Italy ${ }^{96}$, the Court was faced with the inability to register a same-sex couple's marriage in Italy when they were legally married in another country. Thus, the ECtRH had to decide first whether Italy's refusal to register the applicants' marriages as marriages in Italy, violated the Convention. The ECtHR found a violation of the right to family life. It had to determine whether the failure to recognize marriage in any form resulting in the applicants being left in a legal vacuum and without any protection before the new law came into force, violated their rights under Article 8 of the Convention. The Italian government did not prove that there was a prevailing public interest over the applicants' interests, nor did it state any legitimate aim to refuse recognition of their marriages other than a general reference to

92 According to the ECtHR, the goal of protecting families in the traditional sense is quite abstract, and there is a wide range of concrete measures that can be taken to achieve this goal "given that the Convention is a living instrument interpreted in the circumstances of the present moment, the State, in its choice of measures designed to protect the family and to ensure respect for family life under Article 8 of the Convention must take into account the development of relations in the society and changes in understanding of social and civil status issues and relationships, including the fact that there is no single choice when it comes to leading someone's family or private life."

93 See note 80

94 Oliari and Others v. Italy (2015)

95 Selanec, (op. cit.) note 71, pp. 112-113

96 See note 12 
"internal public order". Bearing in mind that it is primarily up to the national law to lay down rules on the validity and legal consequences of marriage, the ECtHR accepted that a national regulation governing the recognition of marriage entered into abroad, may serve the legitimate aim of protecting public order. The ECtHR found that until the passage of the new law, the applicants had no legal framework in place to ensure the recognition and protection of their same-sex unions, by which the State violated their right to family life as guaranteed by Article 8 of the Convention. ${ }^{97}$

In the Pajic v. Croatia case, ${ }^{98}$ the ECtRH continued advancing the family rights of homosexual persons. In the case which encompasses a triple challenge to the margin of appreciation doctrine: the concept of "family life", the immigration policy, and the positive obligations doctrine about family reunification, the ECtRH declared that same-sex unions imply a possibility of family reunification ${ }^{99}$ and that same-sex unions should be considered as family life for the purposes of Article $8 \mathrm{ECHR}$ and it put an end to the debate on whether the concept of family for immigration purposes would encompass such unions. ${ }^{100}$ The facts of the case concern a refusal of a family reunification request made by Ms. Pajić, a woman from Bosnia and Herzegovina, in order to be reunited with her female partner, Ms D.B., a Croatian citizen, with whom she had been in a relationship for two years, and with whom she wanted to establish a household and start a business. National authorities dismissed the applicant's request with a summary reasoning indicating that the relevant requirements under the Aliens Act ${ }^{101}$ had not been met. In particular, domestic Courts claimed that union between two same-sex persons could not be considered as marriage or cohabitation. Since family reunification was allowed for unmarried different sex partners, the applicant alleged discrimination on the grounds of her sexual orientation in obtaining a residence permit in Croatia, under Article 14 taken in conjunction with Article 8 of the Convention.

${ }_{97}$ About absence of a Convention right to marriage for same-sex couples (Article 12) see e.g.: Kleine Victoire, M.; de Maillard, V.; Piat, A., The Role of the European Courts in Developing Same-sex couples' rights Team France, Themis competition 2018, Vilnius Semi-Final B - European Family Law, [http:// www.ejtn.eu/PageFiles/17292/WR\%20TH-2018-02\%20TEAM\%20FR.pdf], accessed 02.04.2020 and Puppinck, G.; de La Hougue, C.; Popescu, P., European Centre for Law and Justice, Third Party observations submitted to the ECtRH in the cases of Orlandi \& others v. Italy (no. 26431/12) and Oliari \& A. v. Italy and Felicetti \& others v. Italy (no. 36030/11 18766/11), Strasbourg, 2014, [http://media.aclj. org/eclj/Oliari-Orlandi-v-Italy-ECHR-ECLJ-WO-English.pdf], accessed 02.04.2020

98 See judgment Pajić v. Croatia (2016)

$99 \quad$ Para. 74-77 and para. 85

100 Almedia, G., Family reunification for same-sex couples a step forward in times of crisis-comments on the Pajic ruling of the ECtRH, [http://web.jus.unipi.it/summer-lisbon/wp-content/uploads/sites/3/2016/06/ Gil-Almeida-Family-reunification-for-same-sex-couples.pdf], accessed 02.04.2020

101 Aliens Act, Official Gazette Nos. 79/2007 and 36/2009 
It found that the applicant had suffered discrimination, and that Article 14 in conjunction with Article 8 of the Convention was violated when her request for residence permit for the purpose of family reunification was refused exclusively on the basis of her sexual orientation. This put her unjustifiably at a disadvantage against other persons in a similar situation (unmarried different-sex couples). ${ }^{102}$ The ECtRH finds that the applicant was affected by the difference in treatment based on sexual orientation introduced by the Aliens Act. It noted that under the Croatian legislation in force at the time when the applicant applied for a residence permit, cohabitation and same-sex relationship were regulated in such a way that both heterosexual and same-sex partners could establish a stable relationship. However, at the time, the applicable Aliens Act provided for the possibility of temporary residence for the purpose of family reunification solely for unmarried heterosexual couples. By tacitly excluding same-sex couples from the term "family", the Aliens Act rendered different treatment of persons in similar situations on the grounds of their sexual orientation. The ECtHR found that the arguments given by the Government did not justify different treatment of same-sex and cohabiting (heterosexual) couples that arose from the applicable Aliens Act. It also noted that the national authorities did not justify the difference in treatment on objective and reasonable grounds. It indicated that the case in question did not relate to the question of whether or not the applicant's residence permit in the Republic of Croatia should have been granted, but rather whether the applicant suffered discrimination on the grounds the national authorities considered according to the domestic law, that the same-sex partner was not entitled to temporary residence for family reunification in the Republic of Croatia. ${ }^{103}$

The Taddeucci and McCall v. Italy case ${ }^{104}$ was brought by Mr Taddeucci (an Italian national) and Mr McCall (a New Zealand national) who complained about the refusal of Italian authorities to grant $\mathrm{Mr}$ McCall a residence permit on family grounds. The applicants alleged that this amounted to discrimination based on their sexual orientation. The ECtRH has held that treating same-sex couples differently to opposite-sex couples, for the purposes of granting residence permits

102 See the Overview of the ECtHR case law, Office of the Representative of the Republic of Croatia before the ECtHR, January-February 2016, available at: [https://uredzastupnika.gov.hr/UserDocsImages/dokumenti/PREGLED\%20PRAKSE/PREGLED\%201_16.pdf], accessed 01.10.2019

103 Due to the above decision, the Republic of Croatia had to amend the Aliens Act, which it did by 2017 amendments to the Aliens Act (Official Gazette No. 69/2017) in such a way that Article 56 of the law, was added the subparagraph by regulating the temporary residence of same-sex couples for the purpose of life partnership

104 Taddeucci and McCall v. Italy (2016), also see communicated cases: S.K.K. and A.C.G. and others v. Romania, application No. 5926/20, communicated on 30.03.2020 and Florin Bubuceanu and Victor Ciobotaru and Others v. Romania, application No. 20081/19, communicated on 16.01.2020 
for family reasons, violated the applicants' right to freedom from discrimination based on sexual orientation in the enjoyment of their rights under Article 8 of the Convention. Thus, there had been a violation of Article 14 taken in conjunction with Article 8 of the Convention. Unlike heterosexual couples, same-sex couples were unable to marry in Italy, making obtaining residency impossible. ${ }^{105}$ The ECtHR concluded that Taddeucci and McCall had endured the same treatment as a differently situated group - heterosexual couples who chose not to marry. ${ }^{106}$

The ECtRH's case law, especially starting from the Schalk and Kopf judgement which is undoubtedly a landmark for the rights of same-sex couples to most recent "Italian cases" shows a significant impact on the development of European family law. Because same-sex couples are now deemed to have "family life" and thus are protected by Article 8 of the Convention, those decisions now establish the positive obligation of the State to ensure specific legal framework providing for the recognition and protection of same-sex unions and their family life. Crucially, not providing such a framework constitutes violation of the right to respect for family life enshrined in Article 8 of the Convention. It is important to point out that the Court's jurisprudence on the right of same-sex couples to marry, in contrast with its dynamic interpretation of Article 12 has remained static. ${ }^{107}$

\subsection{AN OUTLINE OF THE EU AND ECtRH COMPETENCE}

The ECtHR has made it clear that it has been closely monitoring how the EU law regulates the status of the persons of same-sex orientation, by pointing to the EU context when presenting essential parts of the reasoning of its particular judgments (Schalk and Kopf judgment). Moreover, the CJEU closely follows the steps on which the ECtHR builds its doctrine (Maruko case). Their mutual relationship and mutual influence has experienced its last phase through recent precedent decisions - the CJEU in Coman case, and the ECtHR "in Italian cases" - Oliari and Others v. Italy and Orlandi and Others v. Italy, preceded by the decision of the US Supreme Court in Obergefell case.

105 Taddeucci and McCall v. Italy, para. 83

106 Ibid, para. 94-95 and para. 93: "While protecting the traditional family is sometimes a legitimate aim under Article 14, the ECtHR held, it was not sufficiently compelling in this case to justify discrimination on the basis of sexual orientation."

107 About critical analysis of the ECtRH's jurisprudence on Article 12 of the Convention in respect of same-sex marriage see: Johnson, P.; Falcetta, S., Same-Sex Marriage and Article 12 of the European Convention on Human Rights, in: Ashford, C.; Maine, A. (eds.), Research Handbook on Gender, Sexuality and the Law (Edward Elgar Publishing, Forthcoming), 2018, available at: [https://ssrn.com/ abstract $=3136642]$, accessed 02.04.2020 
However, the difference in legal order between the convention law and the EU law has far-reaching consequences. In its recent precedent judgement ${ }^{108}$, the ECtHR has unanimously emphasized obligation of the $\mathrm{CoE}$ member states to provide same-sex couples the opportunity to legal regulation of their relationship, since otherwise the right to family life of same-sex couples is violated. The possibility of recognizing same-sex marriage for all legal purposes and situations outside the scope of EU law can only take the form of voluntary harmonization by the $\mathrm{CoE}$ member states. The Convention does not insist on equality of these partnerships with marriage and the ECtHR does not require from the member state to recognize equality of these partnerships with marriage. Therefore, the ECtHR judgments are binding only for the signatories to the Convention against which they have been pronounced, while their implementation, as well as the legal position of the Convention itself in the national law, depends solely on the constitution and the will of the State itself.

Unlike the ECtHR, which has no way of deciding for itself that the legal recognition of same-sex relationship poses an obligation for everyone, the CJEU has been able to go a step further, because EU law is superior to the national laws of Member States, including their constitutions. The decisions of the CJEU are directly binding on all EU Member States. The CJEU is not bound by ECtHR decisions, but ECtHR decisions undoubtedly affect the CJEU and vice versa, as evidenced by the case law of both courts, preceded by the case law of the US Supreme Court. ${ }^{109}$ It is undisputable that the continuous new decisions from both European Courts, but also national courts have produced a range of inspiring jurisprudence. The CJEU's and ECtRH's case law clearly show not only their tremendous influence on national legal systems, but also their mutual influence on each other.

\footnotetext{
108 See notes 12 and 94

109 The main difference in the legal effects of the CJEU decisions and the US Supreme Court decisions lies in the legal effect of the fundamental rights and freedoms guaranteed by the EU to its citizens. In the USA, the fundamental rights and freedoms laid down by the Constitution are equally restrictive to both federal government and the states. The CJEU does not have the competence to require Member States to legalize same-sex marriage in their national laws, but it has the right to require from Member States to recognize same-sex marriages for the purposes of freedom of movement of persons and to harmonize EU law. In this context, in the USA a redefinition of marriage has taken place, whereas the EU has no competence to do the same for the Member States, since mutual recognition of same-sex marriage in no case puts an obligation on Member States to provide a new definition of marriage in their national laws
} 


\subsection{CASE LAW OF THE CONSTITUTIONAL COURT OF THE REPUBLIC OF CROATIA}

The Croatian Constitutional Court has so far decided in abstract and individual control proceedings in several decisions that stand out, directly concerning samesex couples. ${ }^{110}$

The first case is Pajić case in which as stated above, constitutional complaint was lodged by Ms. Pajić, a national and resident of Bosnia and Herzegovina for residence permit in the Republic of Croatia in order to join her female partner. ${ }^{111}$ In the constitutional complaint, the applicant stated that the impugned decision had violated her right to private and family life ${ }^{112}$ contending that she had been discriminated on the basis of her sexual orientation. ${ }^{113}$

The Constitutional Court rejected the applicant's constitutional complaint but in author's view it stated the reasons for which the constitutional complaint should be dismissed and not rejected. ${ }^{114}$ The Constitutional Court found that the challenged decision of the Administrative Court did not violate the applicant's right under Article 14(1) of the Constitution, stating that discrimination under Article 14(1) of the Constitution does not have an independent standing for a constitutional complaint but must be submitted in conjunction with another (substantive) constitutional right. Article 14(1) of the Constitution contains constitutional guarantee against discrimination on any ground in securing a concrete right. Al-

110 See also decisions Nos. U-III-2284/2015, 08.05 .2019 (contentious proceedings in establishing a same-sex partnership, partnership assets and surrendering possession of things); U-IIIBi-2349/2013, 10.01.2018 (failure of the authorities of the Republic of Croatia to conduct an effective investigation into the alleged abuse of a police officer against the same-sex orientation applicant) and U-III-872/2016, 22.03.2017 (contentious proceedings, discrimination against the persons of the same-sex orientation in media, freedom of thought and expression of thoughts. It has also addressed the issue of transgender persons' rights protection regarding the registration of their gender and name change (decisions Nos. U-III-1216/2013, 18.11.2016 and U-IIIB-3173/2012, 18.3.2014, the issuance of a new altered diploma according to a new personal name and gender identity (decision No. U-III-361/2014, 21.11.2017) and the issues of asylum application in the Republic of Croatia, in cases where the asylum seeker or applicant is a transgender person (decision No. U-III-839/2011, 18.05.2011), [www.usud.hr], accessed 01.10.2019; also see communicated cases: Sabalić v. Croatia, application No. 50231/13, communicated on 07.01.2014 and Zahtila and Koletić v. Croatia, application No. 63344/17, communicated on 12.06 .2018

111 Decision of the Constitutional Court No. U-III-1319/2013, 29.05.2013, the decision is not accessible at [www.usud.hr]

112 Article 35 of the Constitution

113 Article 14 of the Constitution

114 See para. 47 of the judgement Pajić v. Croatia, where ECtRH noted that the reasoning of the Constitutional Court's decision is "somewhat confusing" (see para. 16 of the judgement Pajić v. Croatia and para. 8.1-8.2 of the Constitutional Court's decision) 
though the appellant relied in her constitutional complaint on Article 35 of the Constitution and corresponding Article 8 of the Convention, the Constitutional Court found that these provisions were not applicable. The Constitutional Court did not find facts or circumstances that would suggest that in the proceedings before the appellant was discriminated against on any ground. Thus, the Constitutional Court finds her complaint of a violation of Article 14(1) of the Constitution, unfounded. ${ }^{115}$ The Court further pointed out that the applicant had failed to prove that she had previously exhausted all domestic remedies (under the Anti-discrimination Act), recalling the standpoint taken in the Court's Decision No. U-III-1097/2009 of 9 November 2012. ${ }^{116}$ It also notes that the appellant, in the concrete case, did not show that she had used the legal remedy under the Anti-discrimination Act. In this context, there has been no violation of her constitutional right under Article 14(1) and 14(2) of the Constitution.

The analysis of this decision shows that the Constitutional Court rejected the constitutional complaint, inter alia, on the grounds that the applicant had not exhausted the remedy provided for by the Anti-discrimination Act, which is in accordance with the established practice of the Constitutional Court. However, it follows from the "usual practice" of the Constitutional Court that when the applicant has not previously exhausted the remedy provided by the Anti-discrimination Act, the Constitutional Court dismisses the constitutional complaint entirely or partially, for the time being only in the reasoning part of the decision. ${ }^{117}$ However, in this case, the Constitutional Court relied on the merits of the reasoned violation. Such "vague" reasoning of decisions enables the ECtHR to consider the case meritoriously. It is further noted that, in relation to violation of Article 14(1) of the Constitution, the applicant also pointed out a violation of Article 35 of the Constitution, thereby fulfilling the required condition for Article 14(1) of the Constitution, but, regardless thereof, it did not find this article relevant in this case. It should also be noted that at the time of lodging the constitutional complaint (8 March 2013), and passage of the judgment (29 May 2013), the case law had been established by the ECtHR (in Schalk and Kopfv. Austria ${ }^{118}$, and Xv. Aus-

115 It reiterates that discrimination means difference in the treatment of persons in the same or relevantly similar situations without an objective and reasonable justification

116 See e.g. Decisions of the Constitutional Court Nos. U-III-1097/2009, 9.11.2012, Official Gazette No. 130/10 and U-III-4644/2017, 18.04.2019, [www.usud.hr], accessed 01.10.2019

117 See judgment Guberina v. Croatia (2016), outlining two alternative ways of using legal protection under the Prohibition of Discrimination Act

118 The question as to whether same-sex de facto unions would fall within the scope of "family life" was finally solved in the judgement Schalk and Kopf, where the Court considered "it artificial to maintain the view that, in contrast to a different-sex couple, a same-sex couple cannot enjoy 'family life' for the purposes of Article 8" 
tria) ${ }^{119}$ and CJEU (in Römer, Maruko et al.) ${ }^{120}$ At that time, a considerable number of European countries experienced a rapid evolution regarding legal recognition of same-sex couples. Certain provisions of EU law also reflect a growing tendency to include same-sex couples in the notion of "family".

The ECtHR held that Croatia violated the right to non-discrimination under Article 14 taken in conjunction with Article 8 on the Convention. ${ }^{121}$ It found discrimination not only due to the deficiencies existing in the legal system of the Republic of Croatia and failure of the Constitutional Court to eliminate discrimination, but also due to a formalistic interpretation of rights by national authorities $^{122}$ in the procedure prior to the procedure before the Constitutional Court. It should also be noted that this is not an isolated case where national authorities ${ }^{123}$ apply the relevant substantive law norms on the basis of strictly grammatical interpretation, instead of relevant doctrines achievements of the ECtRH and CJEU and other law interpretation methods, such as teleological, comfort etc., taking into account the dynamics of the legal system and social development as a whole and interpreting the norms in order to eliminate discrimination.

The second and the most recent case in which the Constitutional Court, inter alia, dealt with the protection of the rights of persons of same-sex orientation was through abstract control, i.e. in proceedings for a review of conformity with

119 In the judgment Schalk and Kopf $v$. Austria - ECtRH recognized stable emotional same-sex unions as family unions, note 87; In judgment $X v$. Austria - ECtRH held that same-sex partnerships in which partners raise a child together represent a family life union referred to in Article 8 of the Convention, note 89; see also decision Mata Estevez v. Spain (2001) and judgement P.B. and J.S. v. Austria (2010), note 88

120 Although, at the time of lodging the constitutional complaint in this case, the Republic of Croatia was not yet a EU member state but in the pre-accession negotiations for EU membership, the Constitutional Court could have taken the EU legal standards, case law and the achievements of the relevant doctrine into account when dealing with issues of the protection of persons of same-sex orientation. However, the Constitutional Court did not take ECtRH relevant doctrine and consequently did not find any violation concerning constitutional rights, whereas, consequently, the ECtHR found violation of Article 14 of the Convention in that case

$121 \quad$ See note 98

122 It is interesting to note that the couple had been together for three years by the time their case was heard by the Administrative Court, but the court had not evaluated the factual basis of the application because it relied only on Ms. Pajić sexual orientation. In other words, the couple was in stable de facto same-sex relationship, which was maintained by constant visits to Croatia

123 "The extent to which judges acknowledge the existence of an inviolable core the rights implied in such principle and the way in which they interpret it are two factors that have a strong impact on the powers and functions of the legislature. The interpretation of the courts can, indeed, have the effect of urging or even requiring lawmakers to take action, i.e., to pass new legislation or amend existing laws", Gallo, D.; Paladini, L.; Pustorino, P., Same-Sex Couples before National, Supranational and International Jurisdiction, Springer Science \& Business Media, 2013, p. 4 
the Constitution of the Foster Care Act. ${ }^{124}$ This refers to the case in which the request ${ }^{125}$ and the proposals refer to the situation that does not reflect an omission but expresses the will of the legislator i.e. its legislative concept that does not allow same-sex partners to foster care, whereby it excludes them from the possibility to "participate" in certain procedures before competent bodies. The main objection is that because same-sex life partnerships, defined by the Life Partnership Act as a family life union, are included in the scope of family life, and there is no reason to differentiate them from a foster family under the Foster Care Act. This means that exclusion of family members of same-sex partners from the use of foster care service constitutes discrimination based on sexual discrimination.

The Court found that this produced a discrepancy in the legal order because of general discriminatory effects on one social group defined by the specific form of family union in which they lived, and which was conditioned by their sexual orientation. The Constitutional Court rejected the request on the merits, did not accept the proposals, but expressed in its reasoning a position which, in terms of Article 31(1), (2) and (3) of the Constitutional Act on the Constitutional Court of the Republic of Croatia ${ }^{126}$ obliges bodies directly applying the Foster Care Act to interpret and apply it by using the teleological method, in accordance with the Constitution and international instruments binding on the Republic of Croatia. This standpoint aimed mainly at contributing to the interests of foster care beneficiaries and avoiding discontinuity of the foster care procedures for socially vulnerable persons. Thereby the Court decided on the case in a way that is quite rare in its practice. ${ }^{127}$

124 See note 40

125 It is interesting to note that the request for an assessment of the constitutionality of Article 9, point 3, Article 11(3) and Article 13(2) of the Foster Care Act was filed by 33 members of Croatian Parliament, members of the political group of Social Democratic Party, which makes the request admissible since these members make $1 / 5$ of the total number of 151 members of the $9^{\text {th }}$ term of the Croatian Parliament

126 Constitutional Act on the Constitutional Court of the Republic of Croatia, Official Gazette Nos. 99/99, 29/02 and 49/02

127 Thus, for example, the German Federal Constitutional Court proceeds in specific situations where the legislator excluded certain individuals or social groups from the effects of the law, i.e. in cases where the act of the legislator towards a particular individual is seen as an omissions. The persons feeling discriminated before the law have the opportunity to oppose such actions of the legislator, and by provisions of Article 3, paragraph 1 of the Basic Law, demand elimination of a constitutionally unacceptable situation. A special feature here is the content of the operative part of the Court's decision on the substance. In such situations, the Federal Constitutional Court, given the specific nature of the disputed situation and in the interest of the appellant of the constitutional complainant, refuses to declare the relevant law null and void, leaving the legislator the opportunity to eliminate constitutionally unacceptable inequality of citizens, either by abolishing conflicting privileges or by granting the privileges to the deprived individuals. The court performs its function here by declaring the unconstitutionality of a law 
First of all the author welcomes the decision, but disagrees with the form in which it was made, and is minded to agree with the dissenting opinion of two judges of the Constitutional Court. ${ }^{128}$ In the author's view, the decision rendered is not acceptable and it was necessary to repeal the challenged provisions, even though the whole Foster Care Act except deliberate withholding, i.e. omission of same-sex couples from the Law is in accordance with the Constitution. Indeed, the Foster Care Act does not explicitly prohibit persons living in a life partnership from participating in foster care service, but the fact is that the acts of the legislator (knowingly) contributed to legal uncertainty by introducing doubts about the achievements of the equal position of persons living in a life partnership, which was recognized directly by the Life Partnership Act, the Gender Equality Act and the Anti-discrimination Act. In the author's view, the decision did not sufficiently eliminate discriminatory effect of the provision caused by the practice of the legislature itself, ${ }^{129}$ although in practice the decisions of judicial and administrative bodies prohibits the application of the impugned provision in a way that would allow discrimination against persons in a life partnership and thus removes further legal uncertainty related to the application of the impugned provision. Therefore, this decision preserves the minimum respect for the dignity of persons of the same-sex orientation as established by the decisions of the ECtRH. Based on this decision, same-sex (life) partners will therefore have access to the active participation in providing public foster care services same as heterosexual partners, but they could be rejected same as heterosexual partners, who do not fulfil the conditions required by the Foster Care Act.

In light of the above, and in particular regard to only a few decisions of the Constitutional Court directly concerning the rights of persons of same-sex orientation, the conclusion is that the Constitutional Court has made a visible turn in the protection of the the rights of persons of same-sex orientation, especially the same-sex couples' rights. Unlike previously examined case (Pajić case), where the Constitutional Court failed to recognize discrimination and take into account relevant practice at that time and established standards of the ECtRH and CJEU, the Foster Care Act case, definitely outlines the constitutional standpoints that are significant improvements of its practice indicating that it shall ensure equal

if it finds that equality principle before the law in a particular case has been violated, see e.g. BVerfGE $25,236(253) ; 57,335$ (346)

128 See dissent opinions of two judges of the Constitutional Court Lovorka Kušan and Goran Selanec in the Decision of the Constitutional Court No U-I-144/2019 and Others, 29.01.2020

129 See the Aliens Act (notes 101 and 103), which has also caused different treatment based on sexual orientation between persons in a similar situation by tacitly excluding same-sex couples from the concept of "family", and which had to be amended 
opportunity for active participation in providing public foster care services, regardless of the sexual orientation of potential foster persons.

After the Constitutional Court gave an opinion on the definition of marriage as a union between a man and a woman in its Communication on the Citizens' Constitutional Referendum on the Definition of Marriage and after its decision about Foster Care Act, but also other decisions concerning persons of the same sex orientation ${ }^{130}$, it marked a turning point on this issue. Therefore, the Constitutional Court's decision is of practical importance, it is far-reaching and significant in terms of contributing to the upgrading of the constitutional law doctrine of the Constitutional Court.

\section{CONCLUSION}

This highly sensitive issue touching particularly upon the socio-political and socio-cultural values of states has been the subject of intense and in no case simple and easy discussions, which is best indicated by the overview of the national jurisdiction and case law of two European Courts.

The analysis regarding the legal recognition of same-sex relationships and protection of same-sex couples indicates to the conclusion that the road in its evolution was long, but there is no doubt that it has been the road leading towards equality. As it currently stands, on the one hand an increasing number of EU Member States have opened civil marriage for same-sex couples and most Member States provide some form of formal recognition of same-sex relationships, but on the other hand a number of Member States have sought to define marriage as a union exclusively between a man and a woman in their Constitution or in domestic legislation. Therefore, there are still differences in national jurisdiction regarding this issue so that European and international law make efforts to harmonize it by providing adequate answers and clear legal standards to very complex situations. The CJEU and the ECtRH have been successful in doing so and they have managed to establish standards, although each within the limits of their competence. Both European courts undoubtedly have a key role to play in further development of equality of same-sex relationship in Europe, and their case-law and practice are prime examples and an indicator of the achievement when two European courts agree and take the same views on protecting the same issue.

The ECtHR's case law shows growing jurisprudence on non-discrimination of same-sex couples and its decisions now establish the positive obligation of the

$130 \quad$ See note 110 
States to ensure specific legal framework providing for the recognition and protection of same-sex unions and their family life. However, the Court's case-law on the right of same-sex couples to marry (Article 12 on the Convention), in contrast with its dynamic interpretation of Article 12 has, for now remained static.

The CJEU case law shows a consistent and non-discriminatory application to EU citizens, irrespective of their sexual orientation. In the current maximum of its case law, in Coman case, the CJEU could have offered a better protection than the one provided by the Convention. It could have done that by framing the issue as a question of fundamental rights rather than question of internal market law and yet the aim has been achieved, but there would be definitely an additional line of argumentation if the CJEU relied on the rules of fundamental rights. Consequently, based on the CJEU case law, same-sex spouses currently enjoy more rights than informal cohabitations of heterosexual partners. ${ }^{131}$ It remains, therefore, to see how the CJEU would resolve plentiful issues in future cases, e.g. same-sex partnerships (registered or unregistered) or if a same-sex marriage has been contracted outside the EU. Because of the Coman case effect and the fact that a 'spouse' in the Directive 2004/38 is gender-neutral, Croatia (also Bulgaria, Hungary, Latvia, Lithuania, Poland and Slovakia), regardless of what their constitutions are said to mandate, will have to honour same-sex marriages for the purposes of free movement or it is up to the Commission to ensure that.

The purpose of this paper was to provide an answer to the question how the EU and Conventional law standards that have been established regarding the legal recognition of same-sex relationships and protection of same-sex couples influenced a national constitutional standard. The research has led to the conclusion that the two European Courts' case law regarding this issue has a significant influence on the Constitutional Court. The practice ${ }^{132}$ of the Constitutional Court is a clear indication that it has been observing the changes in social attitudes taking into account the national identity of the Republic of Croatia in accordance with its social, political and legal circumstances so that these tendencies have been viewed as a major development in its recent practice. Regardless of the amendment to the Croatian Constitution of a marriage that excludes the possibility of entering into same-sex marriages, the Constitutional Court shows, especially in its opinion on the definition of marriage and through recent practice, that has marked a turning point, whose reasons and effects could and definitely will considerably influence the evolution of the issue in the years to come.

\footnotetext{
$131 \quad$ See Case Banger, note 82

132 See e.g. Decisions of the Constitutional Court Nos. U-I-6111/2012, 9.10.2019; U-III-557/2019 11.09.2019, etc., [www.usud.hr], accessed 10.11.2019 and note 40
} 
In conclusion, it can be said that at present, the judicial competence, rather than the legislative competence is a key objective of the EU achievement of the internal market and the free movement of citizens regarding same-sex couples. The same applies to the ECtRH, which through its case law establishes the positive obligation of the States to ensure a specific legal framework providing for the recognition and protection of same-sex unions and their family life. Overall, it has to be concluded that it is also a key objective at the Croatian national level shown through the constitutional framework and therefore the Constitutional Court's decision is of practical importance, it is far-reaching and significant in terms of contributing to the upgrading of the constitutional law doctrine of the Constitutional Court, which by its recent practice in this issue has expressed its affiliation with the Central European constitutional orders such as German or Austrian legal circle.

\section{REFERENCES}

\section{BOOKS AND ARTICLES}

1. Bačić Selanec, N.; Bell C., Who is a "Spouse" Under the Citizens' Rights Directive? The Prospect of Mutual Recognition of Same-Sex Marriages in the EU, European Law Review, vol. 41, no. 5, 2016, pp. 655-686

2. Barnard, C., The Substantive Law of the EU, The Four Freedoms, Third edition, Oxford University Press, 2011

3. Bell, M., Holding Back the Tide? Cross-Border Recognition of Same-Sex Partnerships within the European Union, European Review of Private Law, vol. 12, no. 5, 2004, pp. 613-632

4. Bodnar, A.; Śledzińska-Simon, A., Between Recognition and Homophobia: Same-Sex Couples in Eastern Europe, in: Gallo, D.; Paladini, L.; Pustorino, P., (eds.), Same-Sex Couples before National, Supranational and International Jurisdictions, Heidelberg: Springer, 2014, pp. 211-245

5. Boele-Woelki, K.; Fuchs, A. (eds.), Legal Recognition of Same-Sex Relationships in Europe, 2nd ed., 2012

6. Crowley, L., Defining the Family and the Scope of Protection Available - Tensions between National Governance and International Expectations, The International Survey of Family Law, London: Jordan Publishing, 2015, pp. 55-74

7. Digoix, M.; Same-sex families and legal recognition in Europe Cham: Springer, 2020

8. Friðriksdóttir, H., The Nordic Model: Same-Sex Families in Love and Law, in: Gallo, D.; Paladini, L.; Pustorino, P., (eds.), Same-Sex Couples before National, Supranational and International Jurisdictions, Heidelberg: Springer, 2013, pp. 161-179

9. Lucić, N., Pravno uređenje braka i drugih oblika životnih zajednica, in: Rešetar, B. et al. (eds.), Suvremeno obiteljsko pravo i postupak, Pravni fakultet Osijek, Osijek, 2017, pp. 61-102

10. Lucić, N.; Duić, D., Muhvić, D., Izvanbračna zajednica: Analiza međunarodnih i europskih normi u svrhu stvaranja nacionalnih standarda, Zbornik radova Pravnog fakulteta u Nišu, no. 86, 2020, pp. 15-38 
11. Petrašević, T., Pravo na spajanje obitelji u EU, in: Župan, M. et.al. (eds.), Prekogranično kretanje djece u Europskoj uniji, monografija, Osijek, 2019

12. Petrašević, T.; Duić, D.; Buljan, E., Prava istospolnih zajednica u Europskoj Uniji s posebnim osvrtom na Republiku Hrvatsku, Strani Pravni život, vol. 61, no. 3, 2017, pp. 145-169

13. Repetto, G., At the Crossroads Between Privacy and Community: The Legal Status of Same-Sex Couples in German, Austrian and Swiss Law, in: Gallo, D.; Paladini, L.; Pustorino, P., (eds.), Same-Sex Couples before National, Supranational and International Jurisdictions, Heidelberg: Springer, 2013, pp. 263-284

14. Rešetar, B., Uvod - odrednice novog obiteljskog prava i postupka, in Rešetar, B. et.al. (eds.), Suvremeno obiteljsko pravo i postupak, Osijek: Pravni fakultet Osijek, 2017, pp. 11-29

15. Rijpma, J., J., You Gotta Let Love Move: ECJ 5 June 2018, Case C-673/16, Coman, Hamilton, Accept v Inspectoratul General pentru Imigrări, European Constitutional Law Review, vol. 15, no. 2, 2019, pp. 324-339

16. Rijpma, J.; Koffeman, N., Free Movement Rights for Same-Sex Couples Under EU Law: What Role to Play for the CJEU?, in: Gallo, D.; Paladini, L.; Pustorino, P., (eds.), Same-Sex Couples before National, Supranational and International Jurisdictions, Heidelberg: Springer, 2013, pp. 455-490

17. Scherpe, J., M., The Legal Recognition of Same-Sex Couples in Europe and the Role of the European Court of Human Rights, The Equal Rights Review, vol. 10, 2013, pp. 83-96

18. Selanec, G., Praksa evropskih i američkih sudova u oblasti pravne regulacije životnih zajednica osoba istog spola, in: Petrić, N., et.al. (eds.), Izvan zakona: Pravna regulacija životnih zajednica parova istog spola u Bosni i Hercegovini, Sarajevo: Sarajevski otvoreni centar, 2016, pp. 73-119

19. Toner, H., Migration rights and same-sex couples in EU law: a case study, in: Boele-Woelki, K.; Fuchs, A. (eds.), Legal Recognition of Partnerships in Europe, Intersentia 2012, pp. 285-308

20. Tryfonidou, A., The EU Top Court Rules that Married Same-Sex Couples Can Move Freely Between EU Member States as "Spouses": Case C-673/16, Relu Adrian Coman, Robert Clabourn Hamilton, Asociația Accept v Inspectoratul General pentru Imigrări, Ministerul Afacerilor Interne, Feminist Legal Studies, vol. 27, issue 2, 2019, pp. 211-221

21. Tryfonidou, A. EU free movement law and the legal recognition of same-sex relationships: the case for mutual recognition, Columbia Journal of European Law, vol. 21, no. 2, 2015, pp. $195-248$

22. Wintemute, R.; Andenæs, M. (eds.); Legal Recognition of Same-Sex Partnerships - A Study of National, European and International Law, Hart Publishing, 2001

\section{CJEU}

1. Case C-249/96, Lisa Jacqueline Grant v. South-West Trains Ltd., [1998], ECLI:EU:C:1998:63

2. Joined Cases C-122/99 P and C-125/99 P D and Kingdom of Sweden v. Council of the European Union, [2001], ECLI:EU:C:2001:304

3. Case C-459/99 Mouvement contre le racisme, l'antisémitisme et la xénophobie ASBL (MRAX) v. Belgian State, [2002], ECLI:EU:C:2002:461 
4. Case C-60/00 Mary Carpenter v. Secretary of State for the Home Department, [2002], ECLI:EU:C:2002:434

5. Case C-291/05 Minister voor Vreemdelingenzaken en Integratie v. R. N. G. Eind, [2007], ECLI:EU:C:2007:771

6. Case C-127/08 Blaise Baheten Metock and Others v. Minister for Justice, Equality and Law Reform, [2008], ECLI:EU:C:2008:449

7. Case C-267/06, Tadao Maruko v. Versorgungsanstalt der deutschen Bühnen, [2008], ECLI:EU:C:2008:179

8. Case C-147/08 Jürgen Römer v. Freie und Hansestadt Hamburg, [2011], ECLI:EU:C:2011:286

9. Case C-434/09 Shirley McCarthy v. Secretary of State for the Home Department, [2011], ECLI:EU:C:2011:277

10. Case C-34/09 Gerardo Ruiz Zambrano v. Office national de l'emploi (ONEm), [2011], ECLI:EU:C:2011:124

11. Case C-267/12 Frédéric Hay v. Crédit agricole mutuel de Charente-Maritime et des DeuxSèvres, [2013], ECLI:EU:C:2013:823

12. Case C-443/15, David L. Parris v Trinity College Dublin and Others [2016], ECLI:EU:C:2016:897

13. Case C-673/16 Relu Adrian Coman and Others v. Inspectoratul General pentru Imigrări and Ministerul Afacerilor Interne, [2018], ECLI:EU:C:2018:385

14. Opinion of Advocate General Wathelet, Case C-673/16, ECLI:EU:C:2018:2

15. Case C-89/17 Secretary of State for the Home Department v. Rozanne Banger [2018], ECLI:EU:C:2018:570

\section{ECtHR}

1. Convention for the Protection of Human Rights and Fundamental Freedoms, ETS No. 005

\section{Communicated cases:}

1. S.K.K. and A.C.G. and others v. Romania, application No. 5926/20, communicated on 30.03.2020

2. Florin Buhuceanu and Victor Ciobotaru and Others v. Romania, application No. 20081/19, communicated on 16.01.2020

3. Zahtila and Koletić v. Croatia, application No. 63344/17, communicated on 12.06.2018

4. Sabalić v. Croatia, application No. 50231/13, communicated on 07.01.2014

\section{Decisions retrieved from HUDOC:}

1. Sabine Boeckel and Anja Gessner-Boeckel v. Germany, No. 8017/11, 07.05.2013

2. Mata Estevez v. Spain, No. 56501/00, 10.05.2001 


\section{Judgments retrieved from HUDOC:}

1. Burden v. UK, No 13378/05, 29.04.2008

2. Christine Goodwin v. UK, No 28957/95, 11.07.2002

3. Guberina v. Croatia, No 23682/13, 22.03.2016

4. Karner v. Austria, No 40016/98, 24.07.2003

5. Oliari and Others v. Italy, Nos $18766 / 11$ and $36030 / 11,21.07 .2015$

6. Orlandi and Others v. Italy, Nos 26431/12; 26742/12; 44057/12 and 60088/12, 14.12.2017

7. P.B. and J.S. v. Austria, No 18984/02, 22.07.2010

8. Pajić v. Croatia, No. 68453/13, 23.02.2016

9. Schalk and Kopf v. Austria, No 30141/04, 24.06.2010

10. Ratzenböck and Seydl v. Austria, No 28475/12, 26.10.2017

11. Taddeucci and McCall v. Italy, No 51362/09, 30.06.2016

12. Vallianatos and Others v. Greece, Nos 29381/09 and 32684/09, 07.11.2013

13. X. v. Austria, No 19010/07, 19.02.2013

\section{EU LAW}

1. Charter of Fundamental Rights of the European Union, OJ C 326, 26.10.2012

2. Directive 2004/38/EC of the European Parliament and of the Council of 29 April 2004 on the right of citizens of the Union and their family members to move and reside freely within the territory of the Member States amending Regulation (EEC) No 1612/68 and repealing Directives 64/221/EEC, 68/360/EEC, 72/194/EEC, 73/148/EEC, 75/34/EEC, 75/35/ EEC, 90/364/EEC, 90/365/EEC and 93/96/EEC, OJ L 158

3. Council Directive $2003 / 86 / \mathrm{EC}$ of 22 September 2003 on the right to family reunification, OJ L 251

4. Directive $2000 / 78$ establishing a general framework for equal treatment in employment and occupation [2000] OJ L303/16

5. Treaty on the European Union (Consolidated version of the Treaty on European Union) OJ C 326, 26.10.2012

6. Treaty on Functioning of the European Union (Consolidated version 2016), OJ C 202, 7.6.2016

\section{LIST OF NATIONAL REGULATIONS, ACTS AND COURT DECISIONS}

1. Aliens Act (Zakon o strancima, Official Gazette Nos. 79/2007 and 36/2009)

2. Amendments to the Aliens Act 2017 (Zakon o izmjenama i dopunama Zakona o strancima, Official Gazette No. 69/2017)

3. Constitution of the Republic of Croatia (Ustav Republike Hrvatske, Official Gazette Nos 56/90, 135/97, 113/00, 28/01, 76/10 and 5/14)

4. Constitutional Act on the Constitutional Court of the Republic of Croatia, (Ustavni zakon o ustavnom sudu, Official Gazette Nos 99/99, 29/02 and 49/02) 
5. Family Act (Obiteljski zakon, Official Gazette Nos 103/15 and 98/19)

6. Foster care Act (Zakon o udomiteljstvu, Official Gazette, No 115/2018)

7. Gender Equality Act (Zakon o ravnopravnosti spolova, Nos 82/2008 and 69/2017)

8. Prevention of Discrimination Act (Zakon o suzbijanju diskriminacije, Official Gazette Nos $85 / 2008$ and 112/2012)

9. Same-Sex Union Act (Zakon o istospolnim zajednicama, Official Gazette No 116/2003)

10. Same-Sex Partnership Act (Zakon o životnom partnerstvu osoba istog spola, Official Gazette No 92/2014)

\section{Decisions of the Constitutional Court of the Republic of Croatia}

1. No. U-III-839/2011, 18.05.2011

2. No. U-III-1097/2009, 09.11.2012

3. No. U-III-1319/2013 29.05.2013

4. No. U-III-3173/2012, 18.03.2014

5. No. U-III-1216/2013, 18.11.2016

6. No. U-III-872/2016, 22.03.2017

7. No. U-III-361/2014, 21.11.2017

8. No. U-IIIBi-2349/2013, 10.01.2018

9. No. U-III-4644/2017, 18.04 .2019

10. No. U-III-2284/2015, 08.05.2019

11. No. U-I-144/2019 and Others, 29.01.2020

12. Communication on the Citizens' Constitutional Referendum on the Definition of Marriage No. SuS-1/2013, 14.11.2013, Official Gazette No. 138/2013

\section{Decisions of US Supreme Court and Other US Federal Courts}

1. Hillary Goodridge and Others v. Department of Public Health, 798 N.E.2d 941 (Mass. 2003)

2. Hollingsworth v. Perry 570 U.S. (2013)

3. Obergefell v. Hodges, 576 U.S. (2015)

\section{Decisions of other national courts}

1. Austrian Constitutional Court, Nos. B 777/03, 12.12.2003; B 1512/03, 14.10.2004.

2. Press release of the decision of the Austrian Constitutional Court, No. G 258/2017, 5.12.2017

3. German Federal Constitutional Courts, Nos. BVerfGE 25, 236 (253) and 57, 335 (346)

4. Hungarian Constitutional Court, Nos. 14/1995 and 32/2010

5. Romanian Constitutional Court, No. 534/18, 18.07.2018 


\section{WEBSITE REFERENCES}

1. [https://blogs.eui.eu/constitutionalism-politics-working-group/paying-lip-service-cjeu-unsurprising-decision-constitutional-court-romania-coman-case/, accessed 04.01.2020

2. [https://www.nytimes.com/2018/06/05/world/europe/romania-ecj-gay-marriage.html], accessed 01.10.2019

3. [https://narod.hr/eu/referendum-o-braku-u-rumunjskoj-90-posto-biraca-podrzava-brakkao-zajednicu-jednog-muskarca-i-jedne-zene], accessed 02.10.2019

4. [https://uredzastupnika.gov.hr/UserDocsImages/dokumenti/PREGLED\%20PRAKSE/ PREGLED\%201_16.pdf], accessed 01.10.2019

5. Almedia, G., Family reunification for same-sex couples a step forward in times of crisis-comments on the Pajic ruling of the ECtRH, [http://web.jus.unipi.it/summer-lisbon/wp-content/ uploads/sites/3/2016/06/Gil-Almeida-Family-reunification-for-same-sex-couples.pdf], accessed 02.04.2020

6. An Analysis of the ECJ ruling in case C-673/16 Coman the right of same-sex spouses under eu law to move freely between EU member states, Research report prepared by Professor Alina Tryfonidou (University of Reading) for NELFA, [http://nelfa.org/inprogress/wp-content/uploads/2019/01/NELFA-Tryfonidou-report-Coman-final-NEW.pdf], accessed 29.02.2020

7. Cojocariu, C., Same-Sex Marriage before the Courts and before the People: The Story of a Tumultuous Year for LGBT Rights in Romania, Verfassungsblog, 25 January 2017, available at: [https://verfassungsblog.de/same-sex-marriage-before-thecourts-and-before-the-people-thestory-of-a-tumultuous-year-for-lgbt-rights-in-romania], accessed 20.06.2020

8. Commentary of the Charter of Fundamental Rights of the European Union, [https://sites. uclouvain.be/cridho/documents/Download.Rep/NetworkCommentaryFinal.pdf], accessed 20.06.2020

9. Communication from the Commission to the European Parliament and the Council on guidance for better transposition and application of Directive 2004/38/EC on the right of citizens of the Union and their family members to move and reside freely within the territory of the Member States; [https://eurlex.europa.eu/LexUriServ/LexUriServ.do?uri=COM:2 009:0313:FIN:EN:PDF], accessed 01.10.2019

10. Eurobarometar, Special Eurobarometer 493, Discrimination in the EU in 2019 (publication October 2019), pp. 123-124, [https://data.europa.eu/euodp/en/data/dataset/ S2251_91_4_493_ENG], accessed 02.03.2020

11. European Commission Press Corner: Press release 28 March 2006, Europeans move for love and a better quality of life: [https://ec.europa.eu/commission/presscorner/detail/en/ IP_06_389], accessed 20.062020

12. European Commission upholds free movement of people: [https://ec.europa.eu/commission/ presscorner/detail/en/MEMO_14_9], accessed 29.02.2020

13. Free movement of people: five actions to benefit citizens, growth and employment in the EU, [https://ec.europa.eu/commission/presscorner/detail/en/IP_13_1151], accessed 20.06.2020

14. Handbook, Applying the Charter of Fundamental Rights of the European Union in law and policy making at national level Guidances, [https:/fra.europa.eu/sites/default/files/fra_uploads/fra-2018-charter-guidance_en.pdf], accessed 20.02.2020 
15. [http://www.europeandignitywatch.org/disturbing-decision-by-the-eu-court-of-justice-redefines-the-term-spouses/], accessed 01.10.2019

16. Jänterä-Jareborg, M.; Brattström M.; Eriksson, L., Informal relationships - Sweden, National report: Sweden, 2015, p. 1, available at: [http://ceflonline.net/wp-content/uploads/Sweden-IR.pdf], accessed 02.03.2020

17. Johnson, P.; Falcetta, S., Same-Sex Marriage and Article 12 of the European Convention on Human Rights, in: Ashford, C.; Maine, A. (eds.), Research Handbook on Gender, Sexuality and the Law (Edward Elgar Publishing, Forthcoming), 2018, available at: [https://ssrn.com/ abstract=3136642], accessed 02.04.2020

18. Khan, M., Europe's quiet new culture wars over LGBTI rights, Financial Times, 6 December 2018, available at: [www.ft.com/content/d027b3c8-f902-11e8-8b7c-6fa24bd5409c], accessed 30.03.2020

19. Kleine - Victoire, M.; de Maillard, V.; Piat, A., The Role of the European Courts in Developing Same-sex couples' rights Team France, Themis competition 2018, Vilnius Semi-Final B - European Family Law, [http://www.ejtn.eu/PageFiles/17292/WR\%20TH-2018-02\%20 TEAM\%20FR.pdfg, accessed 02.04.2020

20. Kochenov, D., On Options of Citizens and Moral Choices of States: Gays and European Federalism, Fordham International Law Journal, vol. 33, no. 1, 2009, pp. 156-205, available at: [https://ssrn.com/abstract=1557955], accessed 20.06.2020

21. Latten, J. J.; Mulder, C. H. Partner relationships in the Netherlands: new manifestations of the Second Demographic Transition, Genus, vol. 69, no. 3, 2013, pp. 103-121, available at: [https://doi.org/10.4402/genus-588], accessed 20.06.2020

22. Puppinck, G.; de La Hougue, C.; Popescu, P., European Centre for Law and Justice, Third Party observations submitted to the ECtRH in the cases of Orlandi \& others $v$. Italy (no. 26431/12) and Oliari \& A. v. Italy and Felicetti \& others v. Italy (no. 36030/11 18766/11), Strasbourg, 2014, p., [http://media.aclj.org/eclj/Oliari-Orlandi-v-Italy-ECHR-ECLJ-WO-English. pdf], accessed 02.04,2020

23. Schrama, W., National Report: The Netherlands, 2015, pp. 1-8, available at: [http://ceflonline.net/wp-content/uploads/The-Netherlands-IR.pdf], accessed 01.04.2019

24. Site of the Judicial Network of the EU, Decision of Constitutional Court of Romania, no. 534, 2018. on the exception of unconstitutionality of the provisions of Article 277 (2) and (4) of the Civil Code, [https://curia.europa.eu/rjue/upload/docs/application/pdf/2019-03/ dec_ro_20180718_01_en.pdf], accessed 01.10.2019

25. Special Eurobarometer 493, Discrimination in the EU in 2019 (publication October 2019), [https://data.europa.eu/euodp/en/data/dataset/S2251_91_4_493_ENG], accessed 02.03 .2020

26. Szeibert, O., National Report: Hungary, Informal relationships - Hungary, 2015, available at: [http://ceflonline.net/wp-content/uploads/Hungary-IR.pdf], accessed 01.04.2019 